\title{
What Drives the Speed of Job Reallocation During Episodes of Massive Adjustment?
}

\author{
By: Stepan Jurajda and Katherine Terrell
}

William Davidson Working Paper Number 432

January 2002 


\title{
What Drives the Speed of Job Reallocation during Episodes of Massive Adjustment?
}

\author{
Štěpán Jurajda \\ CERGE-EI \\ CEPR, IZA, WDI
}

\author{
Katherine Terrell \\ University of Michigan** \\ CEPR, IZA, WDI
}

January 2002

\begin{abstract}
This paper uses individual-level data to characterize economy-wide job creation and destruction during periods of massive structural adjustment. We contrast the gradualist Czech and the rapid Estonian approach to the destruction of the communist economy to provide evidence on selected macroeconomic theories of reallocation with frictions. We find that gradualism (slowing down job destruction) effectively synchronizes job creation and destruction. Drastic job destruction leads to little or no slowdown of job creation. Small newly established firms are the under-researched fountainhead of jobs during the transition from communist to market oriented economies.
\end{abstract}

JEL classification: E0, J2, O1, O4, P2.

Keywords: Job Creation, Job Destruction, Transition.

This material is based upon work supported by the National Science Foundation under Grant No. 0111783. Any opinions, findings, and conclusions or recommendations expressed in this material are those of the author(s) and do not necessarily reflect the views of the National Science Foundation.

* A joint workplace of the Center for Economic Research and Graduate Education, Charles University, Prague, and the Economics Institute of the Academy of Sciences of the Czech Republic. Address: CERGEEI, POB 882, Politických vězn̆ů 7, Prague 1, 111 21, Czech Republic; Tel.:+420-2-24005-139; E-mail: stepan.jurajda@cerge-ei.cz

** William Davidson Institute, University of Michigan Business School, Ann Arbor, MI 48109. Tel: (734) 615-4558; E-mail: terrell@umich.edu

Acknowledgements: We would like to thank Michael Castanheira, Guido Friebel, Jan Hanousek, Joep Konings, Hartmut Lehmann, Pavle Petrovic, Gerard Roland, Jan Svejnar and especially, John Ham, for numerous helpful discussions and valuable suggestions. Raul Eamets provided us with important information on Estonian statistics. We benefited from comments of participants at the IZA/WDI Conference on "Labor Markets in Transition Economies," the CEPR/WDI Annual International Conference on Economics of Transition, and of seminar participants at LICOS of the Catholic University of Leuven, the University of Michigan, and CERGE-EI. The data collection was supported by NCEEER grant no. 814-13g. Jurajda gratefully acknowledges support from Volkswagen Stiftung through grant no. II/75 828. 


\section{Introduction}

Less-developed countries frequently experience massive shocks that require major adjustments in their economies and also appear to establish turning points, differentiating between multiple growth equilibria (Pritchett, 2000). What is significant about these restructuring episodes is extensive labor movement (across industries as well as within), restructuring or closing of firms in lowproductivity sectors, and the creation of firms in high-productivity sectors. Among the causes of such adjustment episodes are brisk trade liberalizations, external shocks, e.g. oil, and recently, the collapse of totalitarian central-planning regimes. ${ }^{1}$

Reallocation frictions can thwart or even disable the transition process so that the times of adjustment are often times of employment crises. When it is clear which sectors need to be scrapped and which ones need to be built-up, governments can take an active role in affecting the speed of both processes. There are two main classes of economic models that deal with this policy issue of (supply-side) adjustment of the productive structure. Importantly, they differ in their policy prescription.

First, a strand of models that we refer to as the Optimal Speed of Transition (OST) theory, emulates the post-soviet economies and studies the reallocation of labor from the inefficient old state sector to the newly established private sector (e.g., Aghion and Blanchard, 1994; Castanheira and Roland, 2000). ${ }^{2}$ Note, however, that these models can also be applied to economies in the developing world, where a major economic sector is inefficient and bloated. ${ }^{3}$ The shared essence of the various OST models are macroeconomic mechanisms which make the pace of job creation in the efficient sector depend on the speed of job destruction in the inefficient sector. The outcome is that both too much and too little destruction slows down creation; the literature advocates a gradual phasing out of the inefficient sector as optimal for maximizing the speed of job creation and hence reallocation.

Second, there is a large body of theoretical research, building on the notion of "creative destruction," that explains job flows in developed economies as stemming from a continuous stream of allocative shocks (e.g., Aghion and Howitt, 1992; Caballero and Hammour, 1994).

\footnotetext{
${ }^{1}$ To give examples consider (i) the abandoning of import substitution policies and the adoption of trade liberalization and other market oriented policies (including considerable privatization) in South Asia in the 1970s and in Latin America in the 1980s, (ii) the oil shocks to the Middle East or Latin America, and (iii) the collapse of the soviet rule in Europe and Central Asia in the early 1990s. Note that in the post-soviet countries the period of adjustment, coined as "transition," is characterized by the simultaneous adjustments in both economic and political institutions.

${ }^{2}$ Other examples include Burda (1993), Katz and Owen (1993), Chadha and Coricelli (1994), Atkeson and Kehoe (1996), Rugerone (1996), Brixiova (1997), and Boeri (1999). For a survey, see Roland (2000).
} 
Within this literature, Caballero and Hammour (1996a) develop a model of the reallocation process during massive structural adjustments in less developed economies. Their two-sector model based on the embodiment of technology in capital explores the effects on reallocation of incomplete contracting in labor and capital markets. Contracting frictions in their model account for the adjustment crises of less-developed countries — the periods of dramatic destruction of productive capacities, insufficient job creation and high unemployment. The upshot of their analysis is that governments should not only actively slow down the destruction process (similar to the OST prescription) but also boost job creation to attain efficient reallocation.

Hence, the distinction between the two theoretical literatures is important for evaluating gradualism, traditionally defined as slowing down the scrapping of the inefficient sector, as an effective way of avoiding high unemployment during a major change in the economic environment. As Caballero and Hammour (1996a) note: "The real test is whether gradualism can close the wedge between creation and destruction to help redress the transitional employment problem."

Unfortunately, very little empirical evidence is available on job reallocation in economies undergoing major structural reallocation to substantiate the extensive theoretical literature. ${ }^{4}$ This is in contrast to the vast research documenting job reallocation (and its cyclicality) in the U.S. where empirical stylized facts are available for motivating and evaluating business cycle theories (e.g., Davis, Haltiwanger, and Schuh, 1996). Analysis of economy-wide job flows in periods of radical adjustment is needed to develop and refine theories of structural reallocation. Here, the experience of transition economies provides a fruitful opportunity because it represents an unusually extensive experiment of restructuring. First, there are countries experiencing a similar reallocation process under different policies. Second, drastic job reallocation is not constrained to a particular industry, e.g. steel, or region, but is truly economy-wide, offering a striking case for the evaluation of macro models of aggregate reallocation mechanisms. Third, comprehensive micro data on job and/or worker flows are available in many of these countries.

In this paper we use uniquely comparable micro data to produce consistent macro information on the dynamics of economy-wide job reallocation during the dramatic adjustment period following the collapse of communism in two countries - Estonia and the Czech Republic operating under markedly different economic policies. While the Czech approach to destruction of the communist economy was gradual, Estonia's early transition was characterized by extensive

\footnotetext{
${ }^{3}$ Such as the oil-revenue-dependent public sector in the Middle East. See, e.g., Pissarides (2000).

${ }^{4}$ Davis and Haltiwanger (1998) survey the little evidence available on job reallocation in developing countries. The limited literature from transition economies is discussed in Section 2.2. See Offer (1999) for a discussion of similarities and differences between "development" and "transition".
} 
scrapping of old state firms. This difference occurred on a similar background of rapid price and foreign-trade liberalization.

The reallocation theory cited above provides an anchor for our empirical analysis. We describe the patterns of job reallocation in both countries, ask about the usefulness of the two strands of models for understanding the observed reallocation patterns, and discuss the optimality of the observed policy conditional on the validity of each theory and its assumptions. ${ }^{5}$

The plan of this article is as follows: We begin, in Section 2, by considering the predictions of the two sets of models of adjustment/reallocation. Section 3 provides a background on the existing empirical job reallocation literature in transition. The data are described in Section 4, followed by a discussion of our estimation strategy and the complementarity of firm and worker level data in measuring job destruction and creation. In Section 5 we present the empirical findings and discuss them in view of each theory. Section 6 concludes.

\section{Theoretical Predictions}

\subsection{Creative Destruction with Frictions}

A large class of models, which build on the notion of "creative destruction," explain the patterns in the U.S. job creation (JC) and job destruction (JD) as stemming from a continuous stream of allocative idiosyncratic shocks related to technology improvements and changing competition. Within this literature, Caballero and Hammour (CH) (1996b) study the implications of contracting difficulties in the formation of production units on the cyclicality and efficiency of job flows. Their analysis is motivated by the problem of "appropriability" arising when joint investments of employers and employees can be appropriated by one of the contracting parties or governments. They argue that the opportunity costs of creating unemployment are lowest during recessions and it is therefore efficient to concentrate job reallocation and unemployment near the trough of a recession. As an efficient economy enters a recession, JD increases first, closely followed by a rise in JC. As the economy is pulling out of the recession, JC and JD fall, again synchronously. Contracting inefficiencies can, however, "decouple" JD and JC and result in an inefficient reallocation, where more unemployment is created with less reallocation. These two patterns are represented in the upper two graphs of Figure 1. The integral between JD and JC where JD $>$ JC $(\mathrm{JD}<\mathrm{JC})$ represents the amount of accumulated (decumulated) unemployment.

\footnotetext{
${ }^{5}$ Studying only two countries prevents us from using a cross-country regression framework, but does allow for an informative analysis of reallocation patterns. Recently, Topel (1999) stressed that a fruitful way to
} 
A similar reasoning about the importance of frictions for reallocation can be applied to the dramatic adjustment episodes of less-developed and post-soviet countries. Indeed, CH (1996a) study the implications of contracting inefficiencies for such adjustment periods in a two-sector reallocation model. Here again, efficient structural reallocation is characterized by a tightly synchronized evolution of JC and JD to avoid the waste of resources and political economy problems through excessive unemployment. Unfortunately, restructuring is thwarted by the high cost of job creation brought about by transactional difficulties. This core feature of their model leads them to reject gradualism, traditionally defined as government support for the collapsing economic sector, as a sufficient optimal policy. They argue that gradualism alone does not effectively synchronize creation and destruction. Instead, they advocate a policy consisting of a combination of "vigorous creation incentives" in the expanding sector and a gradual phasing out of the inefficient production units.

\subsection{Optimal Speed of Transition}

The policy implication of $\mathrm{CH}$ (1996a) is in contrast to that of a strand of models on transition to a market economy - the Optimal Speed of Transition (OST) theory - that supports the traditional notion of gradualism. It studies the intensive transitional off-steady-state growth through more efficient use of existing resources. These models emulate the post-soviet economies by focusing on the reallocation of labor (and capital) from the old, less efficient state sector to the new, more efficient private sector. The shared essence of the various OST models is that the pace of job destruction (layoffs) in the inefficient old sector affects the speed of job creation (hiring) in the new sector. However, the economic mechanisms that relate the speed of JC to the speed of JD vary across these models. ${ }^{6}$

The backbone of the OST literature is the paper by Aghion and Blanchard (1994) where, similar to the $\mathrm{CH}$ models, reallocation frictions occur in the labor market. While the $\mathrm{CH}$ model assumes transaction difficulties, Aghion and Blanchard assume an efficiency wage setting mechanism where high levels of unemployment lower wages. In their model, market forces determine increases in employment in the new private sector; hence, if the cost of labor is high because of high wages and/or taxes, fewer workers are demanded. On the other hand, the

learn about and to test macroeconomic theory is to conduct "detailed empirical studies of the operation of labor markets and the impact of policies and institutions within individual countries."

${ }^{6}$ Both the OST theory and the CH 1996a model take the view of a two-sector economy moving to a onesector economy, which is similar to both the traditional economic development models concerned with moving from a dual sector (modern and traditional) economy to a single modern sector (first developed by Lewis, 1955) and the more recent trade liberalization literature, where the dichotomy is between the import- 
government engineers the downsizing of the state sector through the reduction of subsidies (push) and the creation of generous unemployment benefits (pull). The government must select the rate at which it will reduce the old sector knowing that if it goes too slowly, there will be a low unemployment rate, which will put upward pressure on wages and hence slow down the growth of the new efficient sector. On the other hand, if it downsizes the old sector too rapidly, it will create high unemployment, which will reduce net wage increases. However, as the model suggests, an excess rate of closure tends to reduce the expansion of the tax base, out of which unemployment benefits are assumed to be financed. The government will then have to raise taxes in order to finance unemployment (and welfare) benefits, hence total wage costs increase, dampening the demand for labor in the private sector. Similarly, if workers leave the labor force instead of becoming unemployed, pensions and other social benefits are also government financed.

Hence, the model postulates an inverted "U" relationship between the speed of job creation in the new sector and the level of unemployment. The dynamics of the economy depend on the initial unemployment level, which determines the level of wages and hence private job creation, and on the speed of labor shedding from the old sector. See Figure 2 for an illustration: Suppose that the economy starts from a low level of unemployment $\mathrm{U}_{0}$, which determines the initial level of job creation in the new productive sector to be $\mathrm{JCnew}_{0}$. Suppose further that initially the government sets job destruction in the old inefficient sector to be $\mathrm{JDold}_{0}$. The gap between $\mathrm{JDold}_{0}$ and $\mathrm{JDnew}_{0}$ (denoted as $x$ in the graph) leads to an equal increase in unemployment (from $\mathrm{U}_{0}$ to $\mathrm{U}_{1}$ ) which again leads to a rise of JCnew for the next period. As long as the government continues to set JDold above JCnew, unemployment rises, up to a point where the unemployment rate then feeds back into the system, slowing down the speed of job creation in the new sector. As long as the government does not set JDold too high, the economy converges to a stable level of unemployment at which the rate of job destruction in the old sector equals the rate of job creation in the new sector. Unemployment remains at this equilibrium level until the transition is over and the inefficient sector disappears. ${ }^{7}$ Furthermore, if the government raises the job destruction rate up to JDold* this will maximize job creation and the speed of transition (reallocation).

Three of the graphs in Figure 1 plot the evolution of JCnew and JDold predicted from Figure 2 under three scenarios, which all share the assumption of a low initial level of unemployment and all involve the same total amount of job creation, but achieved in different time span and at differential unemployment. The upper left graph follows job reallocation in the story

competing and export-oriented sectors (see, e.g., Edwards and van Wijnbergen, 1989, for a review). In what follows we do not consider trade liberalization, which has been extensively analyzed.

${ }^{7}$ In Aghion and Blanchard (1994) the inefficient sector can also be restructured and stay in operation. 
we gave immediately above-where the government gradually increases JDold up to JDold*. Here, gradualism synchronizes JC and JD. The pattern is the same for the $\mathrm{CH}$ model, when there are no contracting frictions. The bottom left panel illustrates the too-slow-JDold scenario, where JCnew catches up with JDold, but reallocation (transition) proceeds at a slower pace - below the optimal (*) level - and hence takes longer to complete. Finally, the bottom right panel plots the evolution of our hypothetical economy where the government raises JDold above the maximum JCnew* level. This leads to a sharp slowdown of JCnew and an increase in unemployment (the area between JDold and JCnew). In plotting this scenario, we further assume that the government responds to such a rise in unemployment by quickly slowing down JDold. Again, reallocation takes too long and is too painful in terms of unemployment.

The OST literature is extensive (see, e.g., Boeri, 2000, and Roland, 2000, for a review) and includes models that establish $\mathrm{JD} \rightarrow \mathrm{JC}$ links using different channels and even in the absence of reallocation micro frictions. To mention but one important paper, Castanheira and Roland (2000) develop a dynamic general equilibrium model of endogenous capital accumulation where again the effect of an excessive speed of closure slows down the growth of the new sector. However, their feedback mechanism works via the depression of savings (investment) when the unemployment rate is high. In their model, for an overly slow speed of closures to have negative effects, it is necessary to assume that state-owned enterprises have soft budget constraints (so that wage payments can exceed the marginal product of labor). As long as wages in the old sector are kept low, old-sector firms will see their workers leaving for the new sector (quitting) even if the rate of scrapping of the old sector (layoffs) is too low.

\section{Existing Evidence on Job Reallocation in Transition}

The OST and $\mathrm{CH}$ theories focusing on adjustment in transition or less-developed countries were developed in the absence of well-grounded stylized facts about the reallocation of jobs. In transition research, both the empirical and theoretical work was being undertaken simultaneously; there is now a substantial literature on job and worker reallocation in transition. Most of this research, however, is descriptive and none examines its findings in the light of reallocation theory.

The empirical literature on job creation and destruction typically draws on Davis and Haltiwanger (1992) and uses firm-level data. For example, Konings, Lehmann, and Schaffer (1996) analyze large firm-level data for Polish manufacturing and find most job destruction occurring in

\footnotetext{
${ }^{8}$ Here we assume that the optimal reallocation rate is such that all reallocation occurs in a short period.
} 
the state owned firms, while most new jobs are created in the private sector (which includes privatized firms). Bojnec and Konings (1999) study a sample of 100 Slovenian firms and reach similar conclusions, while Bilsen and Konings (1998) use a sample of 431 firms from Bulgaria, Hungary, and Romania to identify de novo (newly established) private firms as the driving force of job creation during transition.

Unfortunately, the firm-level data sets from transition countries are typically small and/or cover only medium and large firms from only one sector of the economy. They are rarely welldefined random samples and suffer from a sample selection issue coined as "survival bias" in that they are collected in the mid 1990s and therefore miss any firms that have been completely destroyed in the first few years of transition. ${ }^{9}$ While they offer important information on job reallocation, they do not provide a time-consistent coverage of the whole economy.

The exception is a study of Estonia by Haltiwanger and Vodopivec (1999), that uses the same data we rely on in this study. They show a rapid increase in both worker and job reallocation in the early 1990s with the annual worker reallocation rate exceeding 35 percent by 1993 . At the beginning of transition jobs were eliminated at a very high rate, but by 1994 more jobs were being created than destroyed. They offer a detailed description of job and worker flows, but do not link their findings to economic theory.

While the evidence on job reallocation in transition is limited, there is a wealth of studies on worker reallocation across industrial sectors. These studies provide substantial evidence that in all transition economies the size of the agricultural and manufacturing sectors declined, while employment grew rapidly in construction, trade, services, and finance. ${ }^{10}$ Yet, Faggio and Konings (2001) recently use another firm sample from five transition countries to suggest that most job reallocation occurs within industrial sectors and regions, rather than across. Their analysis also suggests that job creation and destruction occur simultaneously within narrowly defined firm types, much in accord with the evidence on excess job reallocation from developed economies (e.g., Davis and Haltiwanger, 1998).

Given that within one or two years the transition process created double-digit unemployment rates in countries where there was no official unemployment for half a century, it is not surprising that the empirical literature has placed enormous emphasis on the level and determinants of unemployment. A large body of literature on flows between the labor market states of employment, unemployment and out-of-the labor force developed. This literature pinpointed the

\footnotetext{
${ }^{9}$ Survival bias may not only affect state-owned enterprises, but can come from the closure of newly established private businesses during (chaotic) early transition.

${ }^{10}$ See Sorm and Terrell (2000) for the Czech Republic, Noorkoiv et al. (1997) for Estonia and Boeri and Terrell (2002) for other countries.
} 
extent to which unemployment was being created by large inflows vs. small outflows and given that outflows were low, led to research on the determinants of outflows. However, the focus was on the impact of institutions (unemployment compensation systems) and not the relative speed of the downsizing of the old sector. (For a survey see Svejnar, 1999, or Boeri and Terrell, 2002.)

Hence, in spite of all the existing empirical work, little is known about the total extent and dynamics of job reallocation from the old state to the newly established private sector. While official statistics exist on private employment, they combine jobs in de novo firms with those in privatized companies. This is potentially problematic given that the literature on performance and restructuring of privatized firms often suggests disappointing results (e.g., Roland, 2000). Consequently, the existing direct empirical evidence on the OST models is sketchy and does not go, for the most part, beyond discussing macroeconomic aggregates. ${ }^{11}$

\section{Data and Measurement Issues}

Our fundamental approach for capturing reallocation in early transition is to define reallocation as the transfer of jobs from the old state to the new private sector. This is in accord with the OST theory, which assumes higher productivity in the new sector relative to the old. ${ }^{12}$ Using data on firms in a large number of emerging market economies, Mitra et al. (2001) show that labor productivity is indeed higher in small firms (which are mostly new) compared to large firms (which are mostly old); this is true independent of the overall progress towards a market economy. New companies are more productive than inherited firms in countries as diverse as Hungary and Ukraine (Mitra et al., 2001, p. 47).

Our measurements of job reallocation are based on uniquely comparable worker-level data sets. Whereas most of the research on job destruction and job creation is based on firm-level data, we have numerous reasons for using worker-level data and, in the end, we feel our results profit from this. First, firm-level data are sketchy in the early part of transition and do not cover the sector we are interested in. I.e., after the collapse of central planning firms no longer felt they had to report to the central statistical agencies and in the absence of effective fines, the firm census system failed as a tool for measuring total employment. Moreover, the statistical offices were not interested in firms with fewer than 20 workers and they were not able to locate most of the newly

\footnotetext{
${ }^{11}$ For example, Aghion and Blanchard (1994) compare the total change in state and private employment between 1989 and 1992 with 1992 unemployment rates in five transition economies. They also compare the average exit rate out of unemployment. They interpret this evidence as broadly consistent with their model.
} 
established firms with more than 20 employees. ${ }^{13}$ Further, the existing firm-level surveys only cover a part of the economy and were only collected in the mid 1990s and therefore suffer from survival bias (see Section 3).

We then turned to data on workers, but unfortunately, the collection of household labor force surveys started only in the mid-1990s, leaving the first crucial years of transition uncovered. ${ }^{14}$ Fortunately, we have located two data sets, one collected in Estonia and the other in the Czech Republic, that have retrospective information on a representative sample of individuals' jobs and employer attributes since the beginning of the transition in each of these countries. We describe these data in Section 4.1 below. Further, Section 4.2 shows how one can construct measures of job creation and job destruction with retrospective individual data that are similar and complementary to those based on firm level data.

\subsection{Data}

Our analysis uses data from two similar retrospective surveys covering the early period of the transition. The sample design differs slightly in the two surveys. The Czech survey was administered in December 1996 to 3,157 randomly selected households throughout the Czech Republic using the sample frame of the official Labor Force Survey. Those individuals who were employed for at least two weeks during the 1991-1996 period were asked questions about their employment histories. We have usable data on 4,786 working individuals who experience 7,926 main jobs. ${ }^{15}$ The Estonian survey was administered in the first quarter of 1995 to 12,246 individuals between the ages of 16 and 75 in 1995; this represents one percent of the population in this age group, randomly selected from the 1989 Population Census. Ultimately 9,608 (77 percent) individuals were interviewed. ${ }^{16}$ In Estonia, we have usable data on 7,928 individuals with at least

\footnotetext{
${ }^{12}$ Similarly, the steady-state models of the cyclicality of job flows (e.g., Caballero and Hammour, 1991; Mortensen and Pissarides, 1994) assume that new entrants/jobs adopt the most advanced technology and are the most profitable in the market and offer highest wages.

${ }^{13}$ Even in the late 1990s, the Czech Statistical Office was unable to accurately capture the number of firms with fewer than 100 employees and their total employment. Further, the ownership classification in the Czech firm census may not be fully reliable and only information on manufacturing firms has been available to researchers. In Estonia, the firm census only collects information on firms with more than 20 employees.

${ }^{14}$ The Czech Labor Force Survey (LFS) starts in 1993 and provides no information on ownership or firm size. In Estonia, the first LFS was launched in the second quarter of 1995.

${ }^{15}$ We have compared the means and distributions of the major demographic characteristics (i.e., age structure, gender, region of residence and household size) of our sample in 1996 with those from the national Labor Force Survey and we find that our sample is representative in terms of these characteristics. See Munich, Svejnar and Terrell (1997) for a description of the survey and sample design as well as the descriptive statistics of the sample relative to the LFS data.

${ }^{16}$ Non-response was attributable to failure to locate an address for the individual ( 9.2 percent), emigration (7.6 percent) death (3.9 percent) and refusal to participate (1.7 percent). Much of the emigration was
} 
one spell of employment; in total they experience 14,465 main jobs. The number of jobs per person in the data is therefore quite low at 1.82 in Estonia and 1.65 in the Czech Republic.

The two questionnaires elicited information on employment and wages up to six years before the time of the interview. The Czech survey traces the characteristics of the respondents' jobs and non-employment spells between January 1991 and December 1996 whereas the Estonian survey asks about employment histories from 1989 to the first quarter of 1995. For each spell of employment there is information on the industry of employment, type of employment and a number of employer attributes. For those that exited their jobs, we also observe the reason for separation. Whereas in both countries there is information on the respondents' wage at the beginning and end of each job, in Estonia respondents were also asked to report their earnings in October of each year. However, wage information from the hyperinflation years of 1990-1991 is not usable. ${ }^{17}$

Using data that relies on recollection of labor activities up to six years before the time of the interview raises questions about "recall bias." However, research indicates that individuals recall traumatic events more readily and changes in the labor market status (rare at 1.7 to 1.8 jobs per person during 6 years) are likely to have been particularly memorable in an economy transiting from a system with many years of steady employment. ${ }^{18}$

An important question arises regarding the classification of privatized firms. Given the evidence on the lack of restructuring of Czech privatized enterprises, one would like to pool the Czech state and privatized jobs into the old sector. An important advantage of the Czech data therefore lies in their unique ability to distinguish privatized firms from de novo private enterprises. ${ }^{19}$ This allows us to easily code jobs as being in the new or old sector.

In the Estonian questionnaire, firm ownership is categorized as state, private, or cooperative/collective. While we do learn when privatization occurs for ongoing jobs in state firms, for jobs starting during our sample period the data do not distinguish jobs in a de novo private firm from those starting in privatized enterprises. Given that Estonian privatization is considered more efficient than that of the Czech Republic in terms of restructuring (Roland, 2000), we categorize

attributed to the return of ethnic Russians to Russia following the Estonian secession from the former Soviet Union. See Eamets (2001).

${ }^{17}$ To form monthly labor market histories, we interpolate wages from the available information.

${ }^{18}$ For Estonia, Noorkoiv et al. (1997) compared the responses on economic activity in 1989 in the 1995 survey with the responses in the 1989 census and found that "the recall data corresponded quite well. The majority of the discrepancies are attributable to changes in labor force definitions."

${ }^{19}$ Respondents are asked about the ownership type of their employer at the end of their employment spell. The choices are, e.g., "newly established private firm," "firm after privatization," "firm in privatization." This is not a perfect measure of ownership. In particular, it is unclear how the respondents consider spin-offs from privatized or state-owned firms. Yet, as we argue above it is the best measure available. 
jobs starting in a private firm as new-sector jobs. However, we keep ongoing jobs in privatized firms in the old sector to highlight the role of de novo firms in reallocation. Following this strategy, the observed growth of the new sector will not be due to reclassification of ongoing jobs. Our choice maximizes comparability across the two countries given the structure of the data and the relative success of Estonian privatization in restructuring. ${ }^{20}$

In the end, we therefore distinguish between three main employment sectors: the old sector (comprised of jobs in the state owned enterprises, cooperatives, and privatized firms), the new sector (including all jobs in de novo private firms and the self-employed as well as jobs of new hires into Estonian privatized firms), and the public sector (public administration, health and education). Our firm-type assumptions carefully mimic the theoretical concepts and fit the available facts from the transition economies. As will become clear soon, they also provide a very powerful way of slicing up the data.

\subsection{Measurement of Job and Worker Reallocation Rates}

Job reallocation is typically measured with establishment (or plant) and firm level data using the following definition (Davis and Haltiwanger, 2000, pp. 2716-7): "Gross job creation in sector $k$ at time $t\left(\mathrm{JC}_{\mathrm{kt}}\right)$ equals employment gains summed over all business units in sector $k$ that expand or start up between $t-1$ and $t$. Gross job destruction in sector $k$ at time $t\left(\mathrm{JD}_{\mathrm{kt}}\right)$ equals employment losses summed over all business units in sector $k$ that contract or shut down between $t-1$ and $t$."

Although job destruction and job creation are traditionally measured with firm data, they can also be measured from worker flow data using information on type of employment separation as pointed out by Blanchard and Diamond (1990) and recently implemented by Haltiwanger and Vodopivec (1999) with the Estonian data. With this type of data, job creation can be defined as hires less quits that are replaced, while job destruction consists of layoffs and quits without replacement. ${ }^{21}$

\footnotetext{
${ }^{20}$ It is not possible to gain full comparability of the new-sector definition across the Czech and Estonian data. However, we have compared the implied Estonian employment evolution to simulations based on realistic assumptions about the hiring rates of de novo and privatized firms and concluded that the differences at the aggregate level are minor. These results are available upon request. An alternative strategy is to also reclassify jobs in privatized firms as new. See Haltiwanger and Vodopivec (1999) for an analysis of the Estonian data that relies on such private/state coding, which is, however, not available in the Czech data.

${ }^{21}$ We calculate our job flow measures taking into account all transitions that occurred within a given time interval. We work with a (random) sample of workers, rather than their population, and study relatively infrequent transitions. Hence, the smaller the data cells (sector x time period), the lower reliability of our estimates of the worker or job flows. In our empirical analysis we concentrate on sector-year or sectorquarter data cells. Using longer time windows undoubtedly increases the precision of our flow estimates, but leaves us with fewer degrees of freedom.
} 
In the Czech (Estonian) questionnaire, we have 13 (21) answers for how someone separated from their job (see the Appendix Tables A.2 and A.3). We define job destruction (JD) as any separations where: 1) the firm was closed down (by the respondent or another employer) and 2) the separation was part of a mass-layoff. The JD rate is the total number of job destructions at a given time $t$, divided by the number of jobs in $t-1 .^{22}$ It is likely the case that some other separations correspond to job destruction as well. For example, it is possible that some reasons for voluntary separations, such as retirement, may have ended in (been induced by) job destruction; hence, our JD measure is likely to be a lower bound estimate. ${ }^{23}$

To measure job creation, we follow the existing literature and use the identity that

$$
\Delta \mathrm{E}_{\mathrm{tk}}=\mathrm{JC}_{\mathrm{tk}}-\mathrm{JD}_{\mathrm{tk}}=\mathrm{H}_{\mathrm{tk}}-\mathrm{S}_{\mathrm{tk}}=\mathrm{H}_{\mathrm{tk}}-\left(\mathrm{Q}_{\mathrm{tk}}+\mathrm{L}_{\mathrm{tk}}\right)
$$

Here, $\Delta \mathrm{E}_{\mathrm{tk}}$ denotes the time change in employment in sector $k, \mathrm{JC}_{\mathrm{tk}}$ and $\mathrm{JD}_{\mathrm{tk}}$ are job creation and job destruction counts in sector $k$ in time $t$ respectively, $\mathrm{H}_{\mathrm{tk}}$ and $\mathrm{S}_{\mathrm{tk}}$ stand for hiring and separation, and $\mathrm{Q}_{\mathrm{tk}}$ and $\mathrm{L}_{\mathrm{tk}}$ are quits and layoffs. The simple identity (1), namely that net employment growth $(\Delta \mathrm{E})$ is the difference between job creation and job destruction implies that $\mathrm{JC}_{\mathrm{tk}}=\Delta \mathrm{E}_{\mathrm{tk}}+\mathrm{JD}_{\mathrm{tk}}{ }^{24}$

Again, this may be considered as a lower bound estimate for JC because JD may be underestimated. In particular, when $\mathrm{Q}_{\mathrm{tk}}>\mathrm{H}_{\mathrm{tk}}$, the estimated $\mathrm{JC}_{\mathrm{tk}}$ measure is negative, informing us that the minimum number of quits not replaced is $-\mathrm{JC}_{\mathrm{tk}}$. Hence, whenever the initial $\mathrm{JC}_{\mathrm{tk}}$ estimate based on layoffs without replacement is negative we add the negative of $\mathrm{JC}_{\mathrm{tk}}$ to our $\mathrm{JD}_{\mathrm{tk}}$ measure and set $\mathrm{JC}_{\mathrm{tk}}$ at zero. ${ }^{25}$

The correction for $\mathrm{JC}<0$ turns out to affect only JD in the old sector, ${ }^{26}$ which comes as no surprise. Underestimation of JD is especially likely in the old firms, where labor shedding is more

\footnotetext{
${ }^{22}$ Unlike Haltiwanger and Vodopivec (1999) who use January-to-January snapshots, we base our results on all observed worker moves within a given time period.

${ }^{23}$ Given that the total separation rate is an upper bound, we can gain some insight into the dynamics of job destruction by comparing the two, see the Appendix Figures A.2 and A.3. Note that firm-level studies also provide only a lower bound estimate on the true job destruction rate because they focus only on reallocation across firms. Transition firm-level studies further underestimate destruction because of relying on only continuing firms (see Section 3).

${ }^{24}$ This strategy of estimating job creation and job destruction rates relies on random sampling to the extent that when we observe a layoff with replacement (not mass layoff) within a given employment category, it is expected to be compensated by hiring of another worker within our sample into this employment category. Layoffs with replacement constitute only about 2\% (3-6.7\%) of all Czech (Estonian) separations.

${ }^{25}$ In our final empirical work, we perform this correction at a more detailed level, checking for $\mathrm{JC}_{\mathrm{tks}}<0$ where $s$ denotes one-digit industry and summing up the corrected $\mathrm{JD}_{\mathrm{tks}}$ across industries within employment sectors $k$ to obtain our final estimate of $\mathrm{JD}_{\mathrm{tk}}$. This additional level of detail changes the corrected JD measure little.

${ }^{26}$ See the appendix Figures A.2 and A.3, which compare the estimated number of jobs destroyed in the old sector based on layoffs without replacement to the corresponding JD measure corrected for $\mathrm{JC}_{\mathrm{tks}}<0$. In both countries, the two series exhibit a similar pattern, but the corrected measure allows us to identify much more JD, sometimes close to the upper bound provided by the separation rate.
} 
extensive and where quits may be used as a welcome opportunity to decrease the firm's workforce without the social and political costs of (mass) layoffs. Further, old firms are shedding older workers with obsolete communist human capital; sending workers to retirement generates lower political and social costs compared to sending workers to unemployment insurance rolls. Hence, we also correct for early retirements, which are most likely the result of job destruction. We add all those retiring up to five years prior to the official retirement age to our JD measure. The effect of this correction on the JD measure is negligible, however.

The use of worker-level data to examine a firm-level phenomenon results in a measure of gross job flows that is not identical to that of the firm-level studies. ${ }^{27}$ Yet, our worker-level data also offer important advantages. Most importantly, the two samples cover all economic activities and all firm sizes in the economy and provide a continuous coverage of the adjustment period. Unlike firm data sets used in the literature on job reallocation in transition (Section 3), our data are based on well-defined random sampling and do not suffer from the so-called "survival bias." Furthermore, no comprehensive data is available on job creation and destruction in small firms during transition. Thus relying on firm data alone would ignore potentially important evidence that one can find using our approach. Finally, our data allow for simultaneous consideration of worker and job flows and lead to a measure of job reallocation that captures within-firm restructuring, which is not discernible with firm level data. Firm level data contain only the changes in total firm (plant) employment. If firms in a given sector maintain constant employment, but layoff and hire an equal number of workers (into different positions), such restructuring would be ignored in a firm-level data set, but is captured in our data.

\section{Results}

The reallocation theories described in Section 2 provide an anchor for our analysis in that we first empirically describe the objects of this literature: job creation, job destruction and the amount, speed and efficiency of worker reallocation (Section 5.1). We use our results to ask about the usefulness of the theoretical models for understanding the observed reallocation patterns and to discuss the optimality of the observed policy, conditional on the validity of each theory and its assumptions in Section 5.2. The background on the Estonian and Czech transition's initial conditions and policies is provided in Appendix A.1.

\subsection{Basic Findings}

\footnotetext{
${ }^{27}$ Note, however, that our measure produces the same net job creation as that based on firm data.
} 


\section{Employment Structure}

Our first major empirical endeavor is to establish the extent of reallocation from the old to the new sector during the Czech and Estonian transitions. Figure 3 shows the number of workers in each of the two main ownership sectors - old (state, privatized, and coops) and new (private firms and selfemployed entrepreneurs) in the first month of each quarter of each year since the start of transition, which is 1991 for the Czech Republic and 1992 for Estonia. ${ }^{28}$ These are the first results available for these two countries on the evolution of the structure of jobs in the old and the new sector from the early part of the transition.

The story told by this figure is most extraordinary: within five years of the "big bang" of economic reforms in the Czech Republic, and within three years for Estonia, more workers were employed in the new sector than in the old in each country. This massive reallocation is not a consequence of reclassification as privatized firms remain in the old sector. Within a few years, the newly established firms provide more jobs than the firms that still remained from the communist economy. ${ }^{29}$ Moreover, in the Czech Republic, the reallocation is apparently not propped by large flows out of the workforce (or labor force). We note that total Czech employment (corrected for population growth) exhibits slow growth over the entire sample period. In contrast, the more rapid Estonian reallocation is characterized by a pronounced decline in total employment. ${ }^{30}$

This result is important for interpreting the "Czech unemployment puzzle." The Czech unemployment rate stabilized between 3 and 4 percent during transition in presence of significant unemployment inflows. This was the exception to the rule of quickly emerging double-digit

\footnotetext{
${ }^{28}$ The time period covered is 1991 to 1996 for the Czech Republic and 1989 to 1995 for Estonia. We do not present the results for the public sector since this is not highlighted in the theory. Moreover the public sector holds on to a stable workforce in both countries. For an alternative definition of employment evolution using the private/state distinction, as opposed to new/old, see the Appendix Figure A.1.

${ }^{29}$ With the exception of new hires into privatized Estonian firms, see Section 4.1. On the other hand, we may be underestimating the extent of restructuring in Estonia as its privatized firms are probably restructuring more than Czech privatized enterprises.

${ }^{30}$ To distinguish between unemployment and out-of-labor-force may be hard in early transition as the artificial notion of communist full labor-force participation fades in importance. Hence, we juxtapose sectoral reallocation with employment dynamics, rather than with unemployment. The employment growth index is corrected for growth of population aged 15 to 65, which rose from $0.5 \%$ in 1991 to 3\% in 1996 in the Czech Republic and was negligible in Estonia. Nevertheless, substantial employment growth remains, which may appear suspicious given the common wisdom of large employment losses during early transition. However, as we argued earlier (Section 4.1) official statistics relying on firm reporting are likely to miss employment in small newly established firms. Indeed, the employment growth rates based on the Czech Labor Force Survey, which was first collected in 1993, are consistent with our statistics. Similarly, we can match the employment decline of early transition reported in the firm census when we ignore employment in small firms. Finally, we note that the decline of Estonian employment in Figure 3 does not include the outflow of native Russians, mainly military personnel, during early transition (Eamets, 2001).
} 
unemployment rates in other transition economies. ${ }^{31}$ One interpretation of the low Czech unemployment is that it was a result of slow restructuring and worker churning within the old sector. Using the new/old distinction to measure reallocation, Figure 3 suggests that low unemployment occurred simultaneously with extensive reallocation. ${ }^{32}$ Even though the fundamental need for reallocation may differ across the two countries, it is remarkable that the degree of reallocation is the same - albeit occurring in a different time span - and that it occurs at much lower employment costs in the Czech economy.

\section{Job Reallocation in Old and New Sector}

Next, it is natural to ask how job reallocation differs by sector. Is there simultaneous job creation and destruction in the declining old sector or in the growing new economy? In Figure 4 we plot the rates of job creation and destruction in each sector over time; the upper two graphs present the share of job reallocation on total economy-wide employment and the lower two graphs present the shares on employment in the relevant sector. ${ }^{33}$ A striking result emerges. Using the new/old distinction allows us to completely separate all job creation from job destruction during early transition. Old firms are hiring only to replace a fraction of separating workers, as job creation in the old sector is very low. Similarly low is job destruction in the new sector with the exception of the Estonian new sector in 1994-95.

Figure 4 also suggests that the two countries followed a very different transition path in terms of their levels of old sector job destruction (JDold) and new sector job creation (JCnew). At the outset of transition, the Estonians destroyed jobs in the old sector at an annual rate of 14 percent of all jobs (or 25 percent of old sector jobs) whereas the Czech JDold rate at the outset was only 8 percent (12 percent) of all (old sector) jobs. ${ }^{34}$ Thereafter the rates fell in both countries, but the decline was gradual in the Czech Republic and steep in Estonia. The level of JCnew was higher in

\footnotetext{
${ }^{31}$ The puzzle has been examined from a number of angles (see, e.g., Boeri and Burda, 1996; Ham, Svejnar and Terrell, 1998). However, this literature has not been fully successful in identifying the main cause for the dramatic divergence between the unemployment rates of the Czech Republic and those of the Central and East European transition economies during 1991 and 1992. This is likely due to the severe paucity of comprehensive micro-level data covering the first years of transition.

32 Aghion and Blanchard (1994) conjecture that the low Czech unemployment rate is a result of large outflows from the labor force and unrecorded private activities. However, in unreported calculations using our data we find that inflows into long-term non-employment have been steady throughout the transition, making labor-force outflow an unlikely culprit for the stabilization of Czech unemployment below 4 percent since 1992. The shadow-economy hypothesis does not appear to be the driving force either according to Johnson, Kaufmann, and Shleifer (1997) who provide estimates of the unrecorded activity based on electricity-consumption. Their estimates imply that the Czech economy consistently ranked among the Central European countries with the lowest share of the shadow economy on GDP.

33 While the lower graphs make the reported job reallocation rates comparable to the traditional measurements, the upper graphs give a more appropriate description of the adjustment/transition process.

${ }^{34}$ See Appendix A.1 for a description of what economic policies were behind this different JDold evolution.
} 
Estonia than the Czech Republic, both at the outset and within two years after the start of transition, when measured as a share of all employment, which was falling in Estonia. During the first two years of transition, this rate was between about 6 and 10 percent of all employment in the Czech Republic and 9 to 12 percent of all employment in Estonia.

An interesting question is to what extent were old-sector firms restructured during transition. We can ask whether the new and old sectors were similar in terms of job reallocation rates at the end of our samples, when they provided an equal share of jobs in each economy. In both countries, the annual sectoral job destruction rates were indeed similar in the old and new sector; the job creation rates, however, were still much higher in the new sectors, suggesting a continuing difference in growth potential.

\section{Worker Reallocation from Old to New Sector}

The plots in Figure 4 imply that JCnew and JDold alone account for the employment patterns seen in Figure 3. While it is traditional to describe reallocation rates by sector, reallocation should occur across sectors during adjustment periods. In Figure 5, we therefore consider the size and nature of worker flows from the old sector to the new sector.

First, to assess the magnitude and timing of the flow, the upper left graph of Figure 5 plots the number of workers moving as a proportion of total employment in our sample using the time of departure from the old sector to define the timing of the flows. In both countries, the first two years of reforms record the highest old-to-new reallocation rates. However, this peak of reallocation is higher in Estonia where we see annual worker old-to-new flows on the order of about 8 percent of total employment, compared to about 6 percent in the Czech Republic. These two years of high reallocation are followed by a decline - to about 5 percent - in the third year of reform in each country. ${ }^{35}$

In Figure 4 we see a much higher JDold rate in Estonia. Does this result in less efficient old-to-new sector outflows, i.e. fewer leaving the old reaching the new sector? ${ }^{36}$ This suspicion is confirmed by the upper right graph of Figure 5, which shows the fraction of old-sector separations resulting in new-sector hires within six months of the separation. The graph suggests that during

\footnotetext{
${ }^{35}$ In the Czech Republic, where our sample frame extends further into transition, we see a gradual and sustained decline in old-new worker flows. However, this is in part due to the nearing end of our sample frame (December 1996) and censoring of ongoing non-employment spells that may eventually end up with new-sector hiring. Note that in Estonia, where we only observe the first four months of 1995, we are unable to estimate the 1995 level of reallocation. Yet, we can count workers completing the transition to the new sector during 1995 into the 1994 reallocation measure.

${ }^{36}$ Efficiency is important as we would like to know the extent to which outflows from old unproductive jobs result in churning among old-sector jobs vs. moving to a new private sector job. For example, OECD (1998)
} 
the peak years of reallocation, a much higher fraction of workers leaving the Czech old sector arrived in new-sector jobs as opposed to those separating from old Estonian firms. ${ }^{37}$

The lower left plot of Figure 5 asks to what extent we find workers leaving the old sector voluntarily vs. being laid off. The graph indicates that in the Czech Republic, where JDold rates never reached very high levels, quits outweighed layoffs for all old-to-new sector moves throughout the transition. Hence, transition was carried out by old-sector workers quitting their traditional jobs for the new sector. In contrast, the dramatic Estonian JDold in 1992-93 is manifested by the dominant role of layoffs for Estonian old-to-new flows.

In the lower right graph of Figure 5, we ask about the wage premium from moving to the new sector. The realized wage gain from the old-to-new move follows a very similar pattern in both economies, starting at about $40 \%$ during the first year of reforms and gradually declining afterwards. We find a similar pattern comparing the median wages of all workers employed in each sector.

One can further investigate the nature of the old-to-new flows. It is interesting to note that while industrial reallocation is an important part of the old-to-new flows, in some years almost a half of all old-new worker moves did not constitute a move across a broadly defined industry classification (15 main ISIC/NACE sectors). Most of the employment (growth) in the new sector can be accounted for by small firms, defined here as firms with less than 100 employees. These firms, provide about $90 \%$ of all new-sector jobs during early Czech transition, bearing the sole responsibility for Czech JCnew and, hence, Czech low unemployment. While the share of small firms on new-sector employment in Estonia is also overwhelming, at over $85 \%$ in the first two years of transition, a significant share of employment comes from firms employing over 100 workers.

\section{Relationship Between JDold and JCnew}

Next, we ask about the nature of the relationship between the two main job flows, JDold and JCnew. This is motivated by the theories that focus on their evolution and potential feedback.

The upper two graphs of Figure 6 plot the contemporaneous values of monthly JDold and JCnew counts together with fitted regression lines. ${ }^{38}$ The surprising feature of the data is that the

\footnotetext{
suggests that there has apparently been substantial labor turnover in Russia in the 1990s. However, it is not clear to what extent this turnover has been efficient in reallocating labor to its best use.

${ }^{37}$ The fraction of completed old-new moves that occurs with less than one month of an intervening nonemployment spell was about $60 \%$ at the outset of transition in Estonia and only somewhat higher at the start of Czech transition. In the second year, almost $80 \%$ of Czech workers who leave the old sector and find a job in the new one make the move within one month, compared to almost $70 \%$ in Estonia.

${ }^{38}$ The underlying time evolution is plotted in the appendix Figures A.4 and A.5.
} 
smooth Czech annual job reallocation measures (of Figure 4) hide a great deal of volatility at the monthly frequency, with most action occurring at the beginning of each calendar year. Yet, it would appear to the naked eye that the two series move closely together; the Czech labor market seems frictionless as any number of jobs destroyed in the old sector is matched in the same month by an equal number of jobs created in the new sector. The $\mathrm{R}^{2}$ of the linear regression of JCnew on JDold and a constant is 0.68 and the slope coefficient is 0.92 with a standard error of 0.07 . The picture is a lot less sharp in Estonia, where a quadratic term is statistically significant in a regression of JCnew on JDold reaching an $\mathrm{R}^{2}$ of only 0.39 .

Given that total Czech employment remains relatively stable, it is not surprising that JDold and JCnew have a stable long-run relationship. ${ }^{39}$ This is confirmed in the lower left graph of Figure 6 , which plots the twelve-month moving average of the monthly JCnew and JDold. While at the outset of Czech transition the filtered JDold exceeds JCnew, job creation soon starts to dominate job destruction and both measures gradually decline in parallel for most of the transition. In Estonia, on the other hand, JDold is the dominating force until late into transition. When JDold skyrockets in Estonia, JCnew appears to grow at a steady rate until it stabilizes almost a year after the peak in JDold. It remains an open question whether JCnew level stabilized because job creation reached a natural level (e.g., having filled the market niche of understaffed market-oriented industries) or whether it was slowed down by other causes (such as the earlier spike in JDold, see below).

\subsection{Interpreting Results in the Light of Theory}

Here we ask about the usefulness of the macroeconomic theory for understanding the observed reallocation patterns. We consider these patterns within each country separately and also try to learn by comparing the gradual Czech vs. rapid Estonian approach to the destruction of the communist economy. In much of our analysis of these patterns we rely on difference-in-differences reasoning to avoid invoking assumptions of equal initial conditions, e.g., the extent of misallocation and/or level of development.

The Czech-Estonian comparison is useful for reasons in addition to their different rates of old-sector scrapping. The Czech transition, in comparison to Estonian, was characterized by extensive appropriability problems (see below for details), which is useful for evaluating the $\mathrm{CH}$ (1996a) theory. Furthermore, the analysis of the Czech low-unemployment transition is perhaps particularly important for the OST literature, which advocates gradual phasing out of the state

\footnotetext{
${ }^{39}$ Indeed, the monthly series are 1-1 co-integrated in the terminology of time series analysis. Both series are non-stationary of unit root; these results are available upon request.
} 
sector as optimal. At the optimal speed of old-sector demolition, significant unemployment does not arise because jobs in the new sector are being created at a pace that balances the rate of decline of the old sector. Contrary to this scenario, most transition countries have experienced quickly emerging double-digit unemployment rates, in the presence of significant growth of the new private sector. Estonia then provides the best available comparison for the extent of restructuring given that its unemployment increased rapidly during early transition.

\section{OST Theory}

First, we ask whether our findings are in accord with the OST theory's perspective and focus. Indeed, the evidence in Figure 3 suggests that the OST models are correct in dividing the economy into these two sectors and focusing on job creation in the new sector and job destruction in the old sector since these two job flows appear to constitute all of job reallocation at the beginning of transition. In other words, the OST literature is correct in ignoring potential job creation in the old sector and job destruction in the new firms. This success may be surprising since our definition of the old sector includes privatized firms, which could be producing new jobs. Further, the potential for a significant level of job destruction in the new sector is perhaps a more serious challenge to OST theory since it is well known from US data that new firms are likely to fail early on (see e.g., Davis and Haltiwanger, 1999). ${ }^{40}$ Indeed, as transition proceeds, there appears to be more churning in the new sector as separations and JD rise. ${ }^{41}$

Second, are our findings in accord with the evolutionary "organic" perspective and the dynamic properties of the OST story? As seen in Figure 3, the job (employment) transfer was "organic," without major breaks due to, e.g., mass privatization. ${ }^{42}$ The theory predicts that the gradual Czech JDold should result in an extended period of moderate, but constant reallocation, which is also the case. Moreover, in the Czech Republic, the economy quickly converged to a stable level of unemployment at which the rate of change of JDold equaled the rate of change of JCnew as prescribed by OST (Figure 6). Whether this pattern corresponds to the optimal rate of reallocation (upper left quadrant of Figure 1) or sub-optimal transition (bottom left quadrant of Figure 1) will be investigated below.

\footnotetext{
${ }^{40}$ High uncertainty characterizes initial phases of transition, implying that new-firm deaths and JD could be high in transition economies. On the other hand, the de novo private firms are likely to locate in the market niches left wide-open by the inappropriate allocation of resources inherited from central planning.

${ }^{41}$ The assumption of government policy being the main driving force behind the speed of job destruction in the old sector also appears realistic. One of the main instruments of such policy was the banking sector. See Appendix A.1 for a description of the relevant early-transition policies in both countries.

${ }^{42}$ Moreover, the curvature of the trajectory describing the increasing size of the new sector in Figure 3 follows the prediction of the Castanheira and Roland (2000) model: slightly convex at first and turning concave later on.
} 
On the other hand, in Estonia there was no extended time period during which JCnew was equal to JDold. Moreover, unemployment was rising. Estonian transition fits the OST story in that rising JDold concurs with a rising JCnew and an increasing flow of workers moving from the old to new sector. This may correspond to climbing up the inverted " $U$ " curve of Figure 2. That is, JCnew grows when JDold shoots up possibly because the government is rapidly downsizing the old sector to speed up transition by raising unemployment and lowering wages. ${ }^{43}$ Here the theory has a clear prediction. If the rapid scrapping of old firms is too fast, we should see a drop in JCnew (bottom right quadrant of Figure 1), but in fact JCnew continues to grow at a steady rate after JDold peaks. Interpreting this evidence within the Aghion and Blanchard (1994) model, this would suggest that the $25 \%$ annual destruction rate in the old sector during the first two years of transition is not too high for Estonia. But then the theory predicts that JCnew should catch up with JDold (upper left quadrant of Figure 1) while in fact JCnew only catches up with JDold late into transition when JDold is already decreasing. Hence, the grip of OST on Estonia is not perfect.

At a very basic level, one may be suspicious about the OST JD $\rightarrow \mathrm{JC}$ feedback prediction because the higher JDold in Estonia (double that of the Czech Republic) coexists with a level of JCnew similar to that in the Czech Republic. Nevertheless, this fact could well fit within the OST theory if the high Estonian JDold is not too high compared to the optimum Estonian rate and the Czech JCnew is lower than the attainable maximum. This seems to be confirmed by the estimation we perform below.

The core of the OST theory, represented in Figure 2, is in the inverted "U" relationship between the speed of job creation in the new sector and the level of unemployment or nonemployment. ${ }^{44}$ We estimate this relationship using the time dimension of our data. ${ }^{45} \mathrm{We}$ regress 24 quarterly observations of JCnew in each country on the corresponding employment level, its square, and a constant. In the regressions, we use employment instead of non-employment because population size remains stable in both countries, and therefore changes in employment capture the (minus of) changes in non-employment over time. These regressions are presented in Figure $7 .^{46}$ In both countries, both coefficients of the quadratic function were individually statistically significant

\footnotetext{
${ }^{43}$ Both countries enjoyed comparable rates of wage growth since the introduction of the Estonian currency.

${ }^{44}$ The motivation for using non-employment instead of unemployment is threefold. First, in Aghion and Blanchard (1994) workers are employed or unemployed; there is no participation decision. Second, they note that pensions and social benefits require tax increases similar to those required by unemployment insurance benefits. Third, distinguishing between unemployment and out-of-labor-force may be hard in early transition. ${ }^{45}$ If the model is correct, the variation we use for estimation comes from the government adjusting the speed of destruction and from the convergence along the OST curve to the level of unemployment where creation equals destruction (see Section 2.2).
} 
at the $5 \%$ level, with correct signs in terms of the OST theory; attempts to estimate a higher-order polynomial failed.

In Estonia, the behavior of JCnew and employment over time track the concave theoretical relationship postulated by OST with a high fit $\left(\mathrm{R}^{2}=0.88\right)$. Using this suggestive evidence about the theory's validity, one can use the estimated patterns to assess the optimality of the actual macroeconomic policies. In this regard, Estonia exhibits a striking resemblance to an optimal transition. JCnew rises as employment decreases (non-employment rises) and most of the reallocation (job creation) occurs at the optimum level of non-employment, i.e., where the mass of points is at $1-\mathrm{E}=0.10$.

The Czech Republic does not conform to the OST models in that employment actually rises. While we can offer no explanation for this finding, we can ask about the insight of OST theory conditional on the (underlying) rise in employment. The insight is further limited in that the Czech "OST regression" attains an $\mathrm{R}^{2}$ of only 0.25 . Still, there appears to be a level of employment maximizing the rate of job creation. In contrast to Estonia, however, the Czech economy passes through this point and most of reallocation occurs at sub-optimal job creation rates at a too-high employment level. ${ }^{47}$

Above, we focus on the essence of the OST theory - the evolution of job and worker flows. Next, we can also ask about the specifics of the proposed channels of JD-JC feedback within particular OST models. First, in the Aghion and Blanchard (1994) model, wages were to be depressed and taxes increased as unemployment rose. Second, in the Castanheira and Roland (2000) analysis, high unemployment would depress savings.

One could reject the Aghion and Blanchard (1994) model by pointing out that taxes were not raised during transition in either of our two countries in spite of growing unemployment. Furthermore, taxes were higher in the Czech Republic where JC exceeded JD throughout transition (see Table A.1 in the appendix for tax revenues). However, given that in the Czech Republic most reallocation occurred as job-to-job flows, unemployment did not need to play a role in depressing wages. Supporting the Castanheira and Rolland (2000) model, savings did remain stable in the gradualist Czech economy and did decrease during the high-unemployment Estonian transition. Yet, the main cause of the savings decline could have been the Estonian hyperinflation.

The Boeri (1999) critique of the OST theories is that they focus too much on push effects of old-sector scrapping decisions as opposed to the pull effects of the new-sector labor market as

\footnotetext{
${ }^{46}$ The horizontal axis of Figure 7 normalizes employment to the base year so as to show more easily rising/falling non-employment (i.e., 1-employment) and to be able to standardize the axes for the two countries.

${ }^{47}$ Recall that efficiency improvement is the result of more new-sector jobs with higher productivity.
} 
the main force of labor reallocation during transition. In the Czech Republic, quits were the dominant way of transfer from the old to the new sector. However, this pattern is in accord with the Castanheira and Rolland (2000) OST model, where old firms that are not forced to layoff massively due to soft budget constraints, but keep wages low, i.e., close to the actual productivity level, will see their workers leaving for the new sector, where wages and productivity are higher. In this respect, it is important to stress that most medium and large Czech firms were affected by wage controls during 1991-1995 (see Flek, 1996). This policy may have made the pulling of labor from old to new sector easier, saving the transition in terms of the Castanheira and Roland (2000) model.

If we observed a very high new-sector wage premium in the Czech Republic, where there were relatively few layoffs from the old sector, but a low premium in Estonia, one might be tempted to interpret the wage premium as a pull factor necessary to lure workers out of their old jobs, signaling that low JDold is a bottleneck for reallocation. However, given the similarity of wage patterns in both countries, the premium is more likely a result of a selection on benefits from moving, where the old-sector workers with the highest potential profits and earnings in the new sector move first. ${ }^{48}$

Our data cover only three years of transition in Estonia, but provide a longer view on the Czech reallocation. The fact that in later transition there was a significant decline in the number of Czech workers moving from old sector to new sector can be interpreted as suggesting that transition was nearly complete five years after reforms started. Alternatively, it may mean that the transition slowed down after the first few years. The narrowing old/new sector wage differential over time might also signal that the transition is nearly over. Since the narrowing is the result of more rapidly rising old sector wages, it may mean that the workers in this sector are becoming more productive over time as the redundant workers leave and differences in labor productivity between the old and new sector is being eroded. On the other hand, the transition may have slowed down because of very soft budget constraints (SBC) in the Czech Republic, where evidence of SBC exists (e.g., Lízal and Svejnar, 2000, and Table A.1). To provide more definitive evidence, future research needs to compare productivity in the old and new sectors at the end of our sampling frame.

In sum we offer some support for the OST theory, including the inverted "U" relationship between employment changes and new-sector job creation, but we reject some of the specific channels of the JD-JC feedback mechanism. Making the strong assumption that the required

\footnotetext{
${ }^{48}$ Recall that our definition of the new sector contains self-employed and small firms where the profit sharing is likely to be high.
} 
fundamental need for reallocation was the same in the two countries, the conclusion in terms of OST would be that while transition is indeed slower with slow JDold, Czechs have spent only two extra years in transition in exchange for much lower unemployment. ${ }^{49}$ Hence, for some the ultimate lesson may be that Czech JCnew was as high as the Estonian JCnew without the cost of mass layoffs and rising non-employment.

\section{CH Theory}

How do the transition experiences of Estonia and the Czech Republic compare to the assumptions and workings of the $\mathrm{CH}$ models discussed in Section 2.1? The theory predicts that in a world with optimal CH policies, i.e., policies that slow down JD and boost JC, we should see synchronization of JC and JD into efficient job reallocation, as in the first graph in Figure 1. This outcome could also arise in a world where there was rapid downsizing of the old sector and no frictions in job creation. However, in a world with frictions, gradual JD and no boost to JC, there will be a "decoupling" of JDold and JCnew and inefficient reallocation, with high unemployment. Finally, rapid JD will make the outcome in the previous situation even worse, as in the top right graph of Figure 1.

What do we know about these two countries' contracting difficulties and the policies $\mathrm{CH}$ refer to? First, with respect to contracting difficulties in the formation of production units, it would appear that the Czech environment is far more problematic than the Estonian environment. The Czech Republic is infamous for its weak legal structure, impotent judicial system, asset stripping ("tunneling" or "looting," see, e.g., Cull et al., 2001), weak collateral rules, ${ }^{50}$ financial markets that lack transparency, poor investment protection, ${ }^{51}$ etc. Hence, it would appear that at least in the Czech Republic, appropriability frictions are important. We believe that the Estonian legal environment was more transparent and open to foreign investment. A number of laws governing the business environment were enacted very early in Estonia's transition (Bankruptcy Law, 1992; Law on Competition, 1993). According to indexes constructed by the E.B.R.D. for the end of the 1990s, Estonia had a better rating of the effectiveness of commercial and company law (EBRD, 2001).

\footnotetext{
${ }^{49}$ Another caveat is that Estonian privatized firms may be more efficient due to a more effective privatization process. This would further shorten the length of Estonian transition in terms of reallocation and restructuring.

${ }^{50}$ At least as late as 1996 creditors in the Czech Republic had to obtain the permission of the debtor in order to seize the collateral for loans in default.

${ }^{51}$ Consider, for example, the case of a highly profitable commercial TV channel (TV Nova) being taken from the original U.S. investor by a local partner (New York Times, 1999)
} 
Second, it is also important to know whether the destruction of the communist economy was complemented with vigorous assistance for job creation. This is especially important for the Czech Republic, given the prevalent contracting difficulties there. Official statistics indicate that there was more overall credit available in the Czech Republic than in Estonia; unfortunately, there is no evidence on the share of bank credit going to small new firms in either country. ${ }^{52}$ Still, survey evidence from Central European countries suggests that their credit markets provide de novo private firms with large amounts of financing from early stages of firm existence and that credit for newly established firms is more available in the Czech Republic than elsewhere (Bratkowski et. al, 1999). We also know that the relative share of GDP allocated to active labor market policies, another source of financing for startup firms, was far lower in Estonia than in the Czech Republic (0.19 percent vs. 0.08 percent during the $1990 \mathrm{~s}$, see Riboud et. al, 2001) ${ }^{53}$ In sum, it appears that Czech job creation did receive substantial support, especially in comparison to Estonian transition.

Are these policy settings consistent with our empirical findings within the $\mathrm{CH}$ theory? It appears that the Estonians followed a rapid policy of job destruction but devoted little resources to boosting $\mathrm{JC}$ in an environment where there were relatively few frictions. The job reallocation patterns in Figure 6 reveal "decoupling" of JC and JD for Estonia occurring at a relatively high level of job creation. The economic environment must have been indeed relatively free of serious contracting frictions to allow for the vigorous creation of new jobs, in spite of the lack of government support. Nevertheless, the rapid JDold was far greater than the rate of job creation in Estonia, leading to a rising high level of unemployment created during this period. It remains an open question whether with JC support, the rate of JCnew would rise above the annual rate of 12 percent of all employment.

On the other hand, the Czech Republic followed gradualist policies in an environment apparently full of frictions and allocated some resources to creating jobs in the new small-scale sector. Our job reallocation measures show powerful synchronization of JC and JD for the Czech Republic, but at a much higher frequency than that considered by $\mathrm{CH}$. Given the presence of frictions, the JC support must have indeed been very effective to result in the ability of the monthly JC to match any JD level. Looking at a filtered time series, we see JD and JC again synchronized, but at a relatively low level of reallocation. Even vigorous JC support therefore did not result in a concentration of reallocation in a short time span as in the efficient $\mathrm{CH}$ reallocation.

\footnotetext{
${ }^{52}$ Our calculations from official statistics indicate that total credit available as a percentage of GDP was about 66-69 percent in the Czech Republic (1991-94) whereas it was only 14-17 percent in Estonia (1994-95).

More importantly, new credit was about 10-12 percent of GDP in the Czech Republic (in 1993-94) whereas it was only 2 percent in Estonia (1994-95).
} 
Neither country therefore appears to closely "fit" the highly stylized $\mathrm{CH}$ model. Yet, one can draw a lesson applying the $\mathrm{CH}$ theory to the Czech evidence in that it appears that the effect of even extensive frictions can be avoided with some support for job creation.

\section{U.S. Empirical Literature}

Finally, let us conclude the discussion of our empirical results on job flows during an unusually deep structural recession with a comparison to the stylized facts from the U.S. literature on the cyclicality of job reallocation. ${ }^{54}$ First, the U.S. job reallocation is large-scale and incessant (in the U.S. on average one job in ten is being created and destroyed every year). Perhaps surprisingly, reallocation rates in the first two dramatic years of transition appear comparable in magnitude to those from the developed world and even fall afterwards. It is important to note, however, that relatively mild job flows in post-communist economies are effective in supporting extensive reallocation from the old to the new sector.

Second, in the U.S. there is a negative correlation between JC and JD over the business cycle, at least in the manufacturing industry. In contrast, we see co-movement of JD and JC over the transitional recession of the early 1990s. There is even strong positive correlation of JD and JC at high frequency, especially in the Czech Republic. How can one explain this difference? Our results are consistent with the Mortensen and Pissarides (1994) and other models to the extent that the dispersion of the shock to individual firms (new versus old) is the driving force of transition, as opposed to the aggregate shock of the collapse of the communist regime. (Aggregate shocks, such as the oil crises, affect all sectors of the economy whereas allocative shocks are dispersed across sectors and firms.)

Finally, another important difference to the U.S. findings on job reallocation is that small firms apparently create and sustain most jobs during transition: Small transition firms not only have high gross creation rates, but unlike in the U.S., they exhibit relatively low destruction rates (see Davis, Haltiwanger and Schuh, 1996, for the relevant U.S. results).

\section{Final Remarks}

This study sheds light on the process of reallocating jobs and workers during economywide structural adjustment in two transition economies-Estonia and the Czech Republic. Using uniquely comparable data in these two countries, we are able to compare and contrast their patterns

\footnotetext{
${ }^{53}$ Moreover the level of government budget per capita was greater in the Czech Republic. The active policies allocated resources to help unemployed start new businesses (see Boeri and Terrell, 2002).
} 
of job creation and job destruction in light of theoretical predictions from two classes of models that deal with job reallocation, but have been applied to different parts of the world. We show that in transition economies reallocation occurs along a single dimension: from obsolete state enterprises to small new private firms. The extent of reallocation is stunning as only a few years into the transition, in each of these countries small de novo firms provide more jobs than large old firms, which existed prior to 1990. Yet, most of transition research focuses on the issue of enterprise privatization as a way of creating the new economy and private sector employment.

This study's contribution to the research on job reallocation is fourfold. First, we extend the existing literature by contrasting in detail the evolution of job reallocation in two economies facing massive adjustment and using different economic policies to deal with the challenge. Second, we describe reallocation for the entire economy, including all firm sizes and economic activities, and not just for one sector as is typical in much of this literature. Third, we illustrate the usefulness of individual-level data for macroeconomic analysis, although we are not the first to do so. Fourth, and most important, we relate the empirical findings to economic theory and bring together two literatures that have not been contrasted before - the gradualist theories motivated by transition from central planning and the creative-destruction-with-frictions literature motivated by adjustment crises of the developing world.

We find that these two bodies of macroeconomic theory are useful in helping us understand the process and needed policies in transition economies. Both countries, under some assumption fit the dynamic pattern of the OST models. Following the OST logic, the Czech process may have been sub-optimal in that it may have been too slow and the Estonian process may have been optimal in terms of maximizing the net present value of output - the optimality criterion of the OST models. However, it only took the Czechs two more years to obtain the same amount of reallocation as the Estonians, with a much lower level of unemployment.

With respect to the Caballero and Hammour (1996b) model, we find that the Czech Republic's pattern of job destruction and job creation is highly synchronized while the Estonian pattern is one of de-coupling at relatively high level of reallocation. We draw the lesson that even in an environment with contracting frictions, one can have synchronization with a low rate of reallocation when there is support for job creation, as there was in the Czech Republic.

Returning to the question in the introductory section posed by Caballero and Hammour (1996a), our research would suggest that gradualism may have redressed the transitional employment problem in the Czech Republic. However, the Czech (Bulgarian, Romanian) soft-loan

\footnotetext{
${ }^{54}$ See, e.g., Davis and Haltiwanger (1990, 1992) and Blanchard and Diamond (1990). For similar analysis from Germany see Boeri and Cramer (1992) and for Italy Contini et al. (1994).
} 
gradualism leads to corruption and reduces the transparency of the economy, such that it may not be a long-run solution. Moreover, the gradual destruction of jobs in the old sector and the policy to keep wages relatively low there, meant that most of the reallocation in the Czech Republic was driven by (likely more productive) workers (selectively) quitting and looking for jobs in the new sector. This type of transition process may therefore weaken the old sector's chances of improving productivity.

Using very different policies, the Czech and Estonian economies ended up with similar levels of reallocation in relatively short time periods. However, the longer-term outcomes of these processes are likely to be dissimilar; future research is needed to shed light on the ramifications for growth of different reallocation processes. First and foremost, studies directly measuring productivity differences can confirm whether this old-new reallocation indeed leads to productivity increases, and whether the new-sector productivity gains depend on the type of reallocation process. Second, the nature of the transition path may make it more or less difficult for the new economy to move into a steady-state creative-destruction reallocation. I.e., the nature of initial restructuring can affect the existence of reallocation sclerosis or labor market segmentation (e.g., Caballero and Hammour, 2000). These are important questions that can be addressed using our approach to more recent data.

Finally, in future work it may be interesting to investigate the institutional determinants of job creation and destruction such as small and medium enterprise start-up procedures, unemployment insurance and welfare, or to measure the effect of active labor-market policies on economy-wide job creation, in order to understand which policies help make the difference.

\section{References}

Aghion, Philippe and Olivier Blanchard (1994) "On the Speed of Transition in Central Europe," NBER Macroeconomics Annual, pp. 283-320.

Aghion, Philippe and P. Howitt (1992) "A Model of Growth Through Creative Destruction," Econometrica 60(2): 323-351.

Atkeson, Andrew and Patrick Kehoe (1996) "Social Insurance and Transition," International Economic Review 37 (2): 377-402.

Berkowitz, Daniel and David N. DeJong (2001) "Entrepreneurship and Post-socialist Growth" unpublished paper, University of Pittsburgh, October.

Bilsen, Valentin and Jozef Konings (1998) "Job Creation, Job Destruction and Growth of Newly Established, Privatized and State-owned Enterprises in Transition Economies: Survey Evidence from Romania, Bulgaria and Hungary," Journal of Comparative Economics, 26: 429-445. 
Blanchard, Olivier and Peter Diamond (1990) "The Cyclical Behavior of Gross Flows of U.S. Workers," Brookings Papers on Economic Activity 2( ): 85-143.

Boeri, Tito (1999) "Transition with Labour Supply," William Davidson Institute Working Paper Number 274, December.

Boeri, Tito and Michael Burda (1996) "Active Labour Market Policies, Job Matching and the Czech Miracle," European Economic Review, 40: 805-817.

Boeri, Tito and Ulrich Cramer (1992) "Employment Growth, Incumbents and Entrants: Evidence from Germany," International Journal of Industrial Organization; 10(4), 545-565.

Boeri, Tito and Katherine Terrell (2002) "Institutional Determinants of Labor Reallocation in Transition," Journal of Economic Perspectives, 16(2) February, forthcoming.

Bojnec, Stefan and Josef Konings (1999) "Job Creation, Job Destruction and Labour Demand in Slovenia," Comparative Economic Studies, Vol. XLI, 135-149.

Bratkowski, A., I. Grosfeld, , and J. Rostowski (1999) "Investment and Finance in De Novo Private Firms: Empirical Results from the Czech Republic, Hungary and Poland," William Davidson Institute Working Paper Number 236.

Brixiova, Zuzana (1997) "On the Speed of Transition in Central and Eastern Europe: Does On-the-Job Search Matter?" IMF Working Paper No. 102.

Burda, Michael (1993) "Unemployment, Labor Markets and Structural Change in Eastern Europe," Economic Policy, 16, 102-137.

Caballero, Ricardo, Eduardo Engel, John Haltiwanger (1997) "Aggregate Employment Dynamics: Building from Microeconomic Evidence,” American Economic Review 87(1): 115-137.

Caballero, Ricardo J. and Mohamad L. Hammour (1994) “The Cleansing Effect of Recessions,” American Economic Review 84(5): 1350--1368.

(1996a) “On the Timing and Efficiency of Creative Destruction," Quarterly Journal of Economics 111 (3): 805-851.

(1996b)"On the Ills of Adjustment" Journal of Development Economics 51: 161-192.

(2000) "Creative Destruction and Development: Institutions, Crises, and Restructuring, " NBER Working Paper No. 7849.

Castanheira, M. and Gerard Roland (2000) "The Optimal Speed of Transition: A General Equilibrium Analysis,” International Economic Review, 41(1): 219-39.

Contini, Bruno, Andrea Gavosto, Riccardo Revelli and Paolo Sestito (1994) "Job Creation and Destruction in Italy" Rome: Bank of Italy. Working Paper.

Coricelli, Fabrizio (1998) Macroeconomic Policies and the Development of Markets in Transition Economies. Central European University Press.

Cull, Robert, Jana Matesova, and Mary Shirley (2001) "Ownership Structure and the Temptation to Loot: Evidence from Privatized firms in the Czech Republic," World Bank Working Paper no. 2568.

Davis, Steven J. and John C. Haltiwanger (1992) "Gross Job Creation, Gross Job Destruction and Employment Reallocation,” Quarterly Journal of Economics, 107(3): 819-863. 
(1999) "On the Driving Forces Behind Cyclical Movements in Employment and Job Reallocation,” American Economic Review, December: 1234-1257.

(2000) "Gross Job Flows," Chapter 41 in Orley Ashenfelter and David Card (eds.) Handbook for Labor Economics, Volume 3B, Amsterdam: North Holland, pp. 2711-2808.

Davis, Steven J. and John C. Haltiwanger, and Scott Schuh (1996) Job Creation and Destruction. Cambridge: MIT Press.

Dyba, Karl and Jan Svejnar (1995) “A Comparative View of Economic Developmnets in the Czech Republic," Chapter 2 in J. Svejnar (ed.) The Czech Republic and Economic Transition in Eastern Europe, Academic Press.

Eamets, Raul and Kaia Philips (1998) "Estonian Labour Market and Labour Policy: Contry Study presented to the International Labour Organization," University of Tartu.

Eamets, Raul (2001) "Reallocation of Labour During Transition: Disequilibrium and Policy Issues, the Case of Estonia." Ph.D. Dissertation, Tartu University.

Faggio, Giulia and Josef Konings (1999) "Gross Job Flows and Firm Growth in Transition Countries: Evidence from Firm Level Data on Five Countries," CEPR Discussion Paper No. 2261.

Faggio, Giulia and Josef Konings (2001) "Job Creation, Job Destruction, and Employment Growth in Transition Countries in the 90s," IZA Discussion Paper No. 242.

Flek, V. (1996) "Wage and employment restructuring in the Czech Republic," Working Paper No.60, Czech National Bank (Ceska Narodni Banka).

Foote, Christopher L. (1998) "Trend Employment Growth and the bunching of job creation and Destruction," Quarterly Journal of Economics, 113 (3): 809-834.

Haltiwanger, John C. and Milan Vodopivec (1999) "Gross Worker and Job Flows in a Transition Economy: An Analysis of Estonia," World Bank Policy Research Working Paper 2082, March.

Ham, John, Jan Svejnar and Katherine Terrell (1999) "Women's Unemployment During the Transition: Evidence from Czech and Slovak Micro Data," the Economics of Transition, 7(1): 47-78.

Johnson, Simon, Kaufmann, Daniel and Andrei Shleifer (1997) "The Unofficial Economy in Transition," Brookings Papers on Economic Activity, 2, 159-221.

Katz, Barbara G. and Joel Owen (1993) "Privatization: Choosing the Optimal Time Path," Journal of Comparative Economics, 17 (4): 715-736.

Konings, Josef, Hartmut Lehmann and Mark Shaffer (1996) "Job Creation and Job Destruction in a Transition Economy: Ownership, Firm Size and Gross Job Flows in Polish Manufacturing, 19881991," Labour Economics, 3: 299-317

Kotrba, Josef and Jan Svejnar (1994) "Rapid and Multifaceted Privatization: the Experience of the Czech and Slovak Republics," MOCT-MOST, 4:147-185.

Lewis, Arthur W. (1955) The Theory of Economic Growth. Homewood, Ill: Richard Irwin Press.

Lízal, Lubomir (2001) "Determinants of Financial Distress: What Drives Bankruptcy in a Transition Economy? The Czech Republic Case," CERGE-EI Discussion Paper No. 68. 
Lízal, Lubomir and Jan Svejnar (2000) "Financial Conditions and Investment during the Transition: Evidence from Czech Firms," CERGE-EI Working Paper No. 153.

Mitra, Pradeep et al. (2000) "Transition After a Decade: Lessons and Agenda for Policy," unpublished World Bank Paper, November.

Mortensen, Dale T. and Christopher A. Pissarides (1994) "Job Creation and Job Destruction in the Theory of Unemployment," Review of Economic Studies 61(3): 397-415.

Munich, Daniel, Jan Svejnar and Katherine Terrell (1997) "Final Report to the Czech Ministry of Labor and Social Affairs on the Retrospective Questionnaire on Employment Histories," Unpublished, May.

New York Times (1999) “American Fights for Control of Prague TV Station,” December 24, International Business Section.

Noorkoiv, Rivo, Peter R. Orazem, Alan Puur and Milan Vodopivec (1997) "How Estonia's Economic Transition Affected Employment and Wages (1989-95)" World Bank Policy Research Working Paper 1837.

OECD (1998) OECD Economic Surveys: Russia. Paris: Organization for Economic Cooperation and Development.

Offer, Gur (1999) "Development and Transition: Distinct or Complementary" unpublished paper, Hebrew University.

Pissarides, C. (2000) "Labor Markets and Economic Growth in the Middle East and North Africa" mimeo, London School of Economics; Global Research Project of the Global Development Network.

Pritchett, L. (2000) "Understanding Patterns of Economic Growth: Searching for Hills among Plateaus, Mountains, and Plains," World Bank Economic Review, 14(2): 221-50.

Riboud, Michelle, Carolina Sanchez-Paramo, Carlos Silva-Jauregui (2001) "Does Edurosclerosis Matter? Institutional Reform and Labor Market Performance in Central and Eastern European Countries," in B. Funck and L. Pizzati (eds.) Labor, Employment and Social Policies in the EU Enlargement Process. World Bank.

Richter, Andrea and Mark E. Shaffer (1996) "Growth, Investment, and Newly-established Firms in Russian Manufacturing," in: Simon Commander, Qimiao Fan and Mark E. Shaffer, eds., Enterprise restructuring and economic policy in Russia. EDI, World Bank, Washington, D.C.

Roland, Gerard (2000) Politics, Markets and Firms: Transition and Economics. The MIT Press: Cambridge, Mass.

Sorm, Vit and Katherine Terrell (2000) "Sectoral Restructuring and Labor Mobility: A Comparative Look at the Czech Republic," Journal of Comparative Economics, September, 28: 431-458.

Svejnar, Jan (1999) "Labor Markets in the Transitional Central and East European Economies," Chapter 42 in Orley Ashenfelter and David Card (eds.) Handbook of Labor Economics, Vol. 3B. Amsterdam: North Holland, pp. 2809-2854.

Topel, R. (1999) “Labor Markets and Economic Growth,” in Handbook of Labor Economics, Vol. 3., ed. O. Ashenfelter and D. Card. Amsterdam: North Holland.

Venesaar, Urve and George A. Hachey (1995) editors of Economic and Social Changes in the Baltic States in 1992-1994. Estonian Academy of Science, Institute of Economics. 


\section{Main Figures}

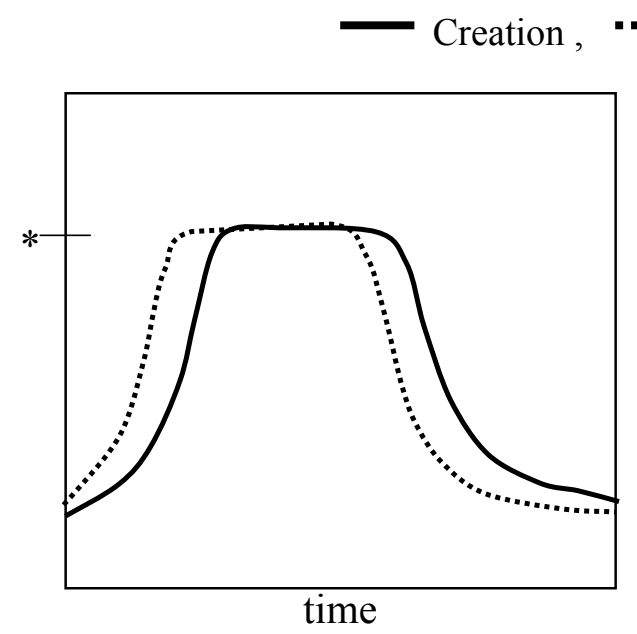

Destruction
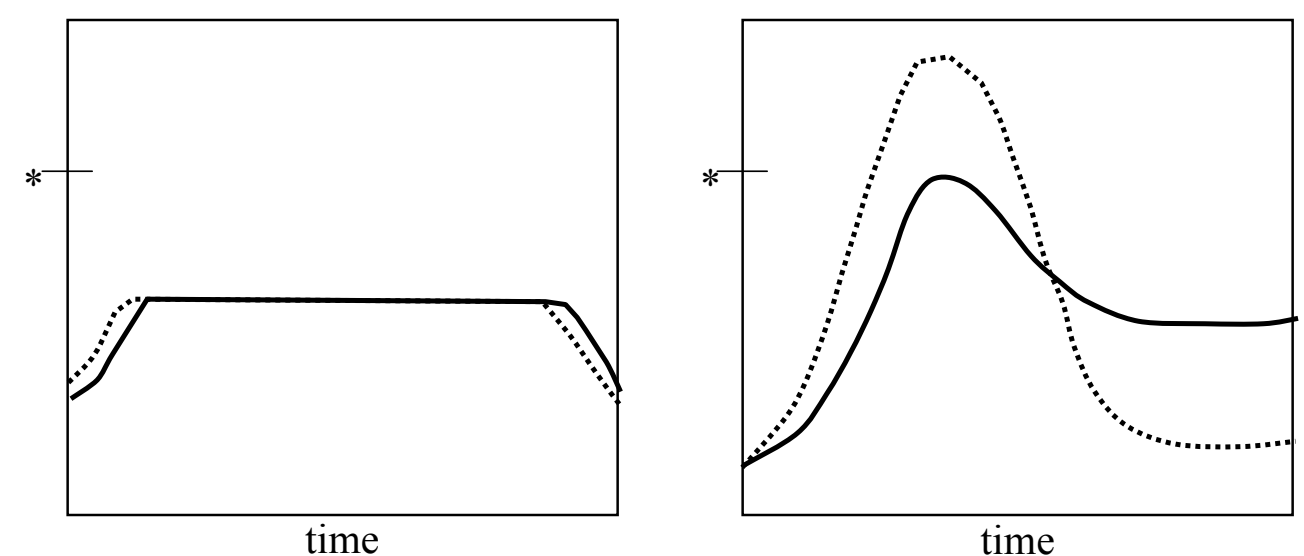

Figure 1: Job Reallocation in OST and CH Theory

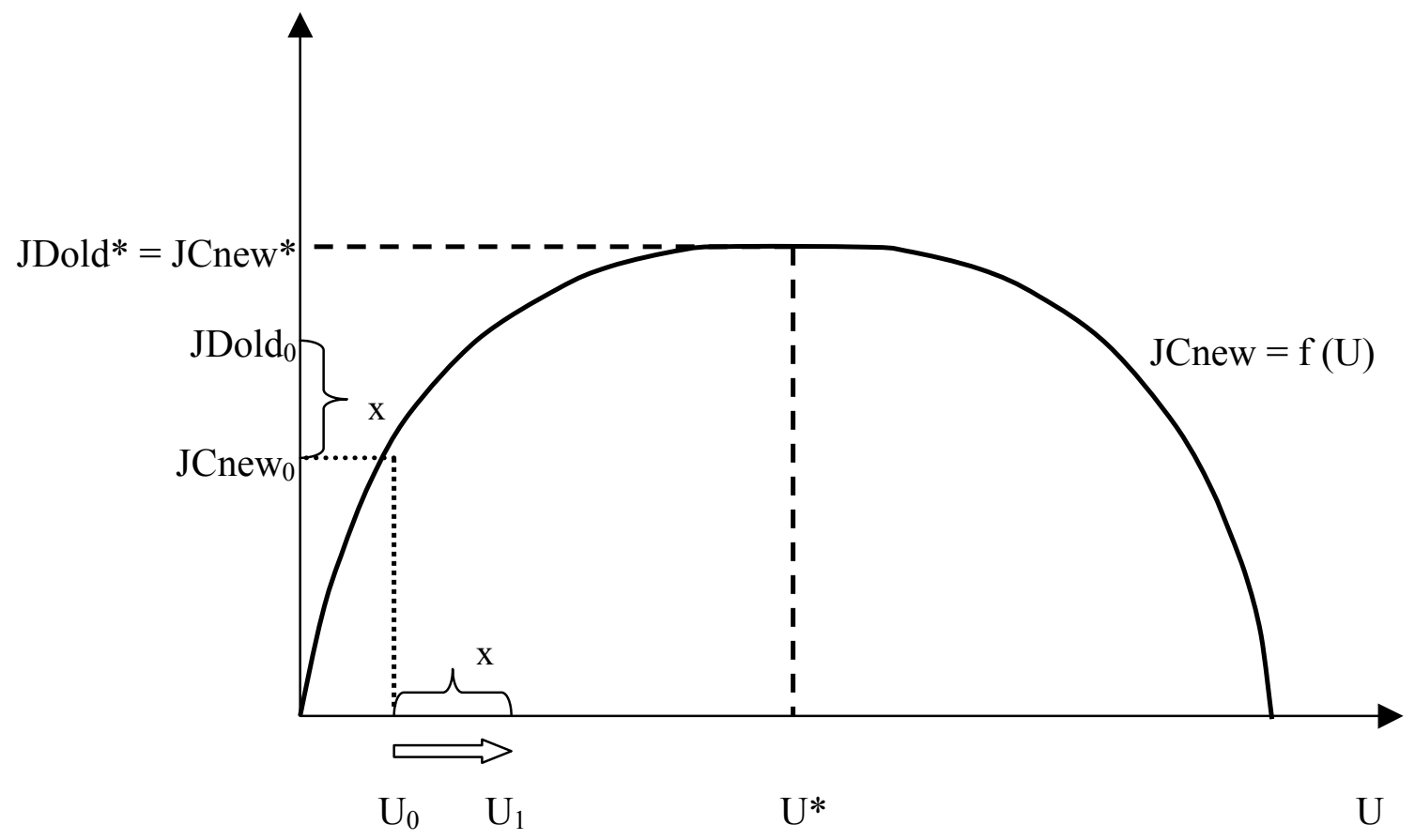

Figure 2: Unemployment and Job Reallocation in OST Theory 


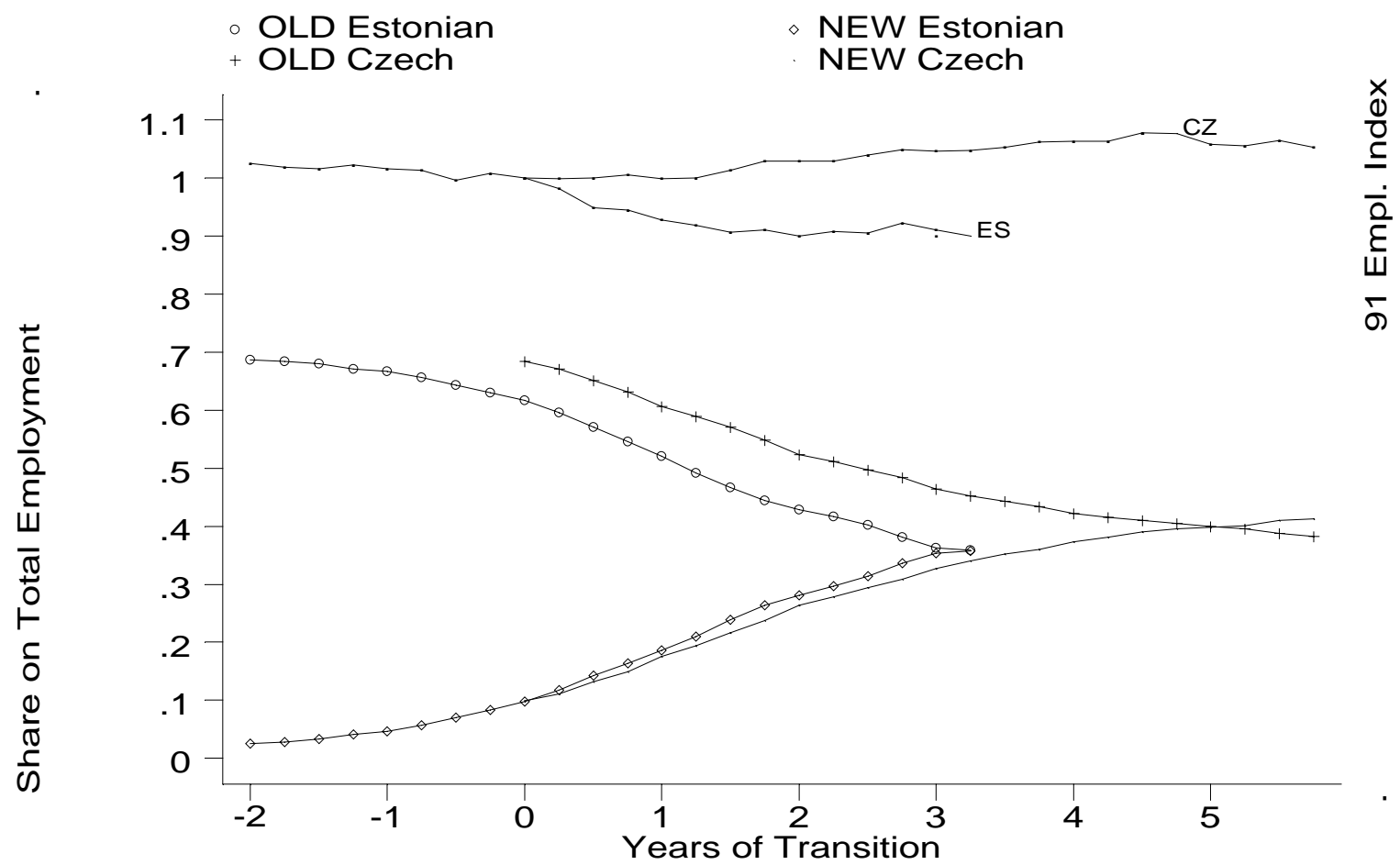

Figure 3: Employment Evolution by Sector
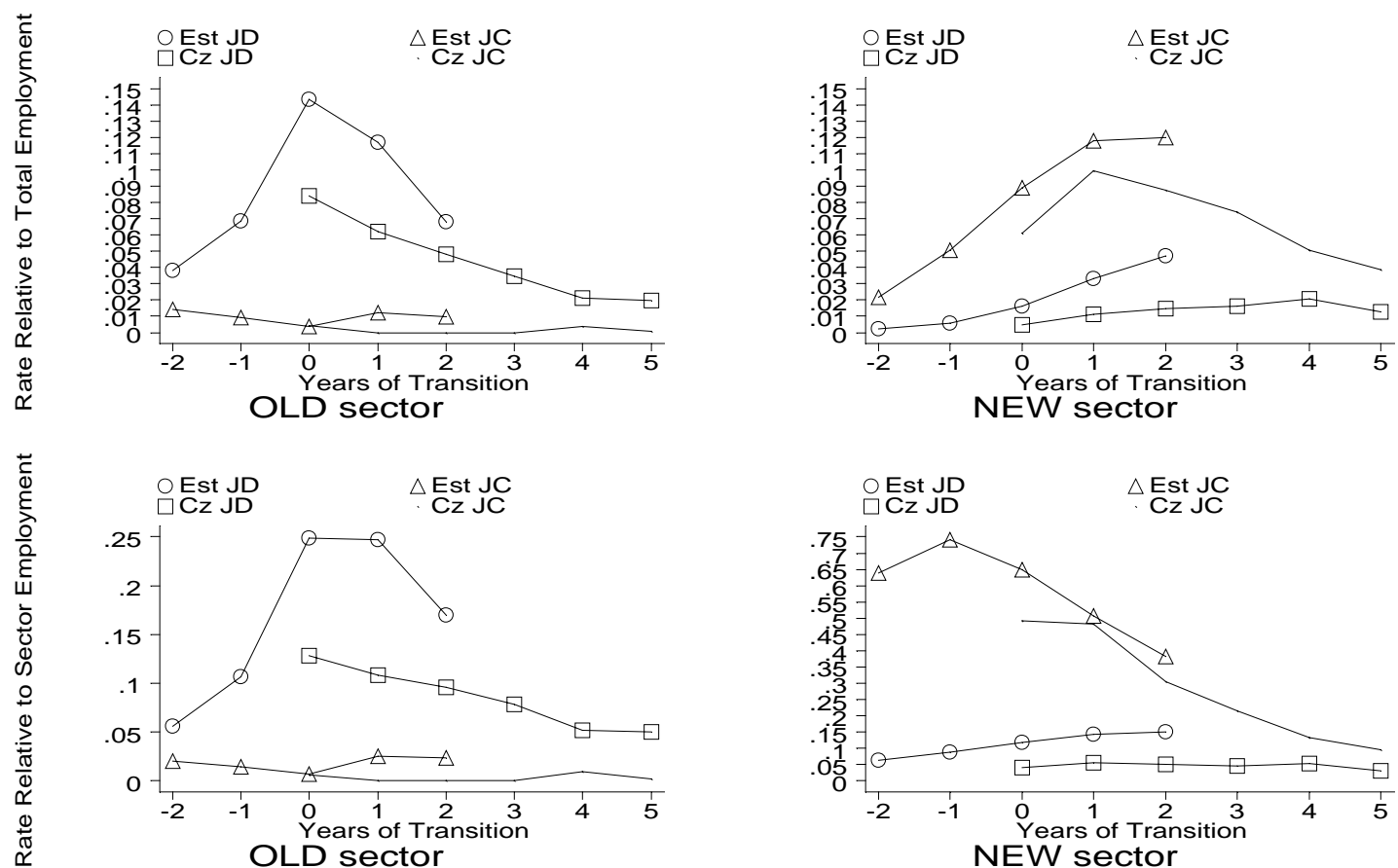

Figure 4: Job Reallocation by Sector 

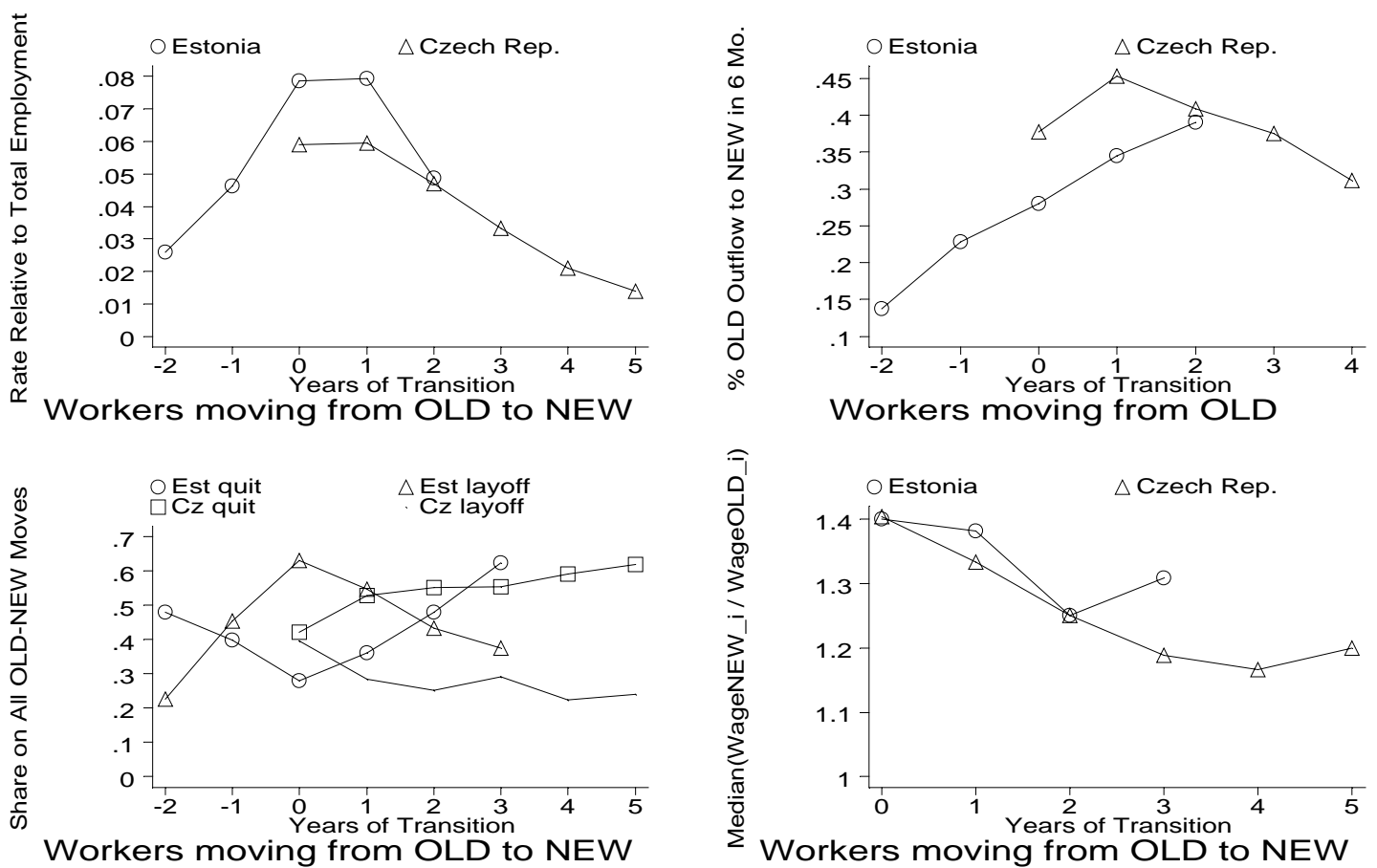

Figure 5: Worker Reallocation from OLD to NEW Sector

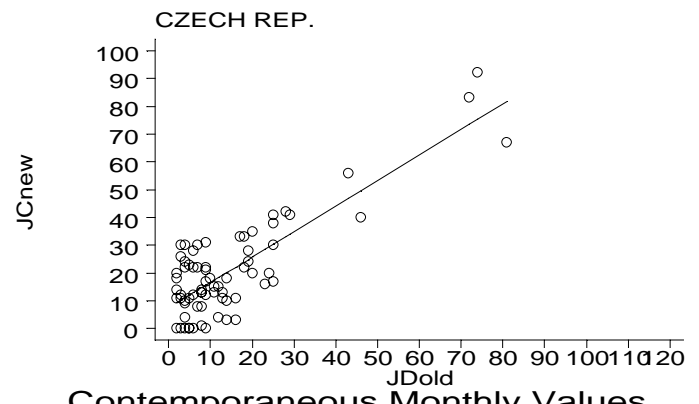

Contemporaneous Monthly Values

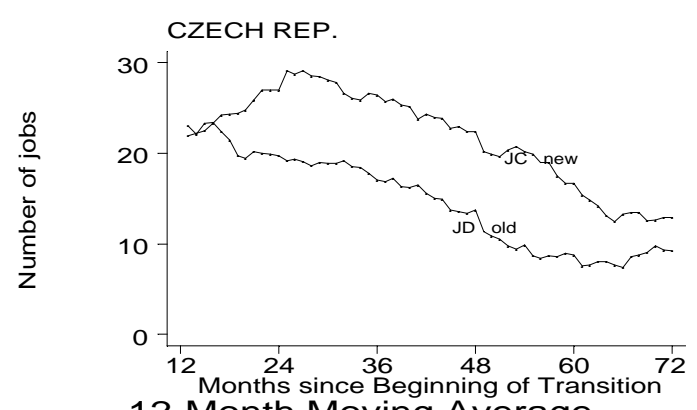

12-Month Moving Average

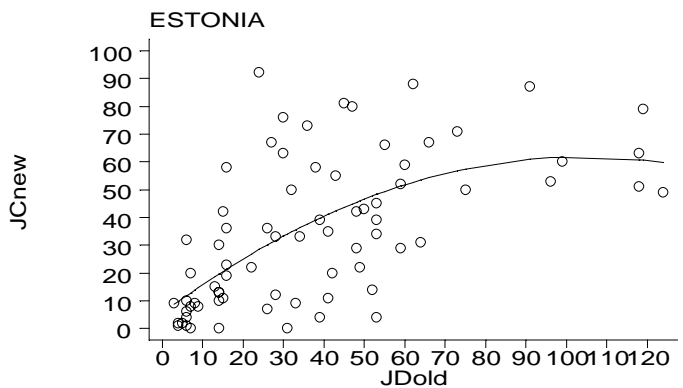

Contemporaneous Monthly Values

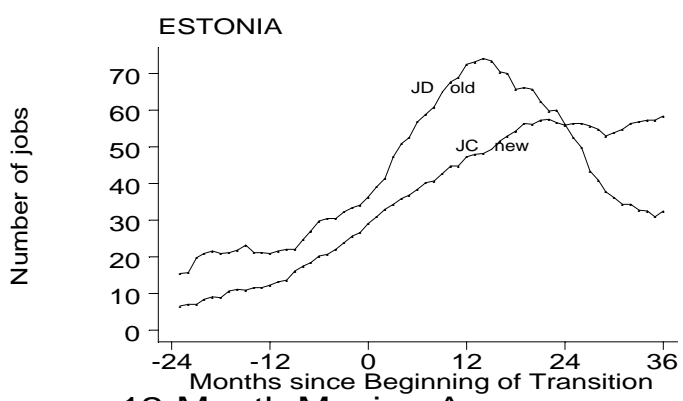

12-Month Moving Average

Figure 6: JDold and JCnew Time Series 

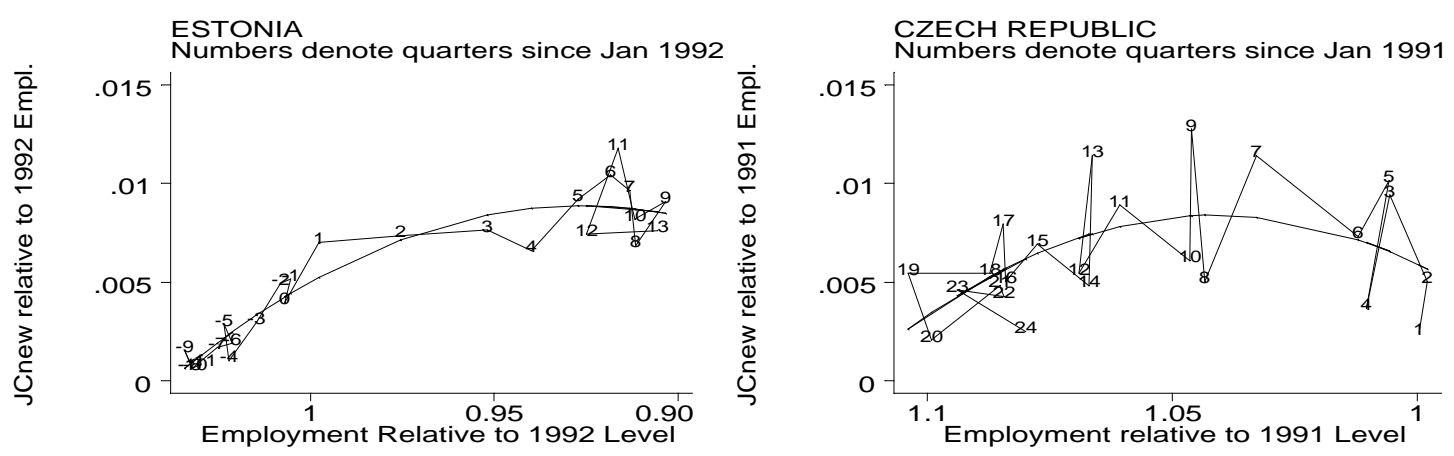

Figure 7: OST Curve 


\section{Appendix A.1 The Transition Experiences of the Czech Republic and Estonia}

Estonia and the Czech Republic are two small countries (populations of 1.5 and 10 million, respectively) that are widely recognized as being among the most market-oriented economies in their regions. ${ }^{55}$ The path and timing of reforms of these two countries were similar in many respects, although starting one year earlier in the Czech Republic. Estonia gained independence from the Soviet Union in 1991 and began liberalizing prices and initiating reforms in 1992 whereas the Czech Republic became free of the soviet rule at the end of 1989 and undertook first macroeconomic and institutional reforms in 1991. (See Dyba and Svejnar, 1995, and Eamets, 2000, for more details.)

At the macroeconomic level, Estonia experienced a deeper and longer recession than the Czech Republic, see appendix Table A.1. ${ }^{56}$ The Estonians also faced far higher levels of inflation throughout the entire period, but especially in its year of price liberalization when the country suffered Ruble hyperinflation of 1,076 percent. (Consequently, while Czech savings as a share of GDP remained stable throughout transition, there was a steep decline in Estonian savings in the early years of transition.) The government responded to runaway inflation by aggressively implementing tight monetary and fiscal policy and established a currency board for a newly established Estonian currency (crown) in July, 1992 (Eamets, 2001).

Whereas the unemployment rate in the Czech Republic peaked at 4.1 percent during the year of price liberalization (1991) and then stabilized at around 3 percent until 1996 (five years after the start of transition), the unemployment rate in Estonia continued to rise the entire period, reaching almost 10 percent in 1996. According to official statistics, by 1996, the end of our period of study, employment levels in Estonia were 77 percent of their 1989 levels and Czech employment was at 93 percent its 1989 level. Finally, real wage declined more in Estonia than in the Czech Republic during the year of price liberalization and hyperinflation, but followed a very similar pattern once the new Estonian currency was introduced.

Given the focus on job destruction in this paper, it is important to understand the privatization and restructuring processes in these two countries, an area where their policies do differ. The Estonian privatization process proceeded much more rapidly than the Czech. The Czechs began with small-firm privatization in 1990-91, which was followed by two waves of large-firm privatization in 1992-93 and 1994-95 (for more detail see Kotrba and Svejnar, 1994).

\footnotetext{
${ }^{55}$ Consequently, both countries are among the candidates for the first wave of EU accession.

${ }^{56}$ The comparison of Estonia and the Czech Republic is essentially comparing the FSU with the CEE in all the above respects (except for the low level of the unemployment rate in the Czech Republic).
} 
In Estonia, small-scale privatization was completed between 1992 and 1994 and large-scale privatization was accomplished mostly in 1992 (Eamets and Philips, 1998).

Moreover, the Estonian privatization included the elimination of subsidies and removal of barriers to exit for state enterprises in 1993, only one year into the transition (Cornelius, 1995). In contrast, bankruptcy laws were effectively not in place until 1996 in the Czech Republic (Lízal, 2001), and its banks remained under control of the government. Many of the old Czech firms continued to receive subsidies hidden as (soft) commercial loans. A state owned bank (Consolidation Bank) set up to clear non-performing loans from the large bank portfolios in the Czech Republic was transformed from a temporary hospital for bad loans inherited from the communist era to a "state run commercial debt-alleviation agency" (Desai, 1996). The largest four banks had long-standing creditor relationships with the voucher privatized SOEs and also made equity investment in these firms through their voucher investment funds. Cull, Matesova, and Shirley (2001) show that such joint stock companies exhibited worse performance and higher indebtedness than privately held limited liability firms. More generally, Lízal and Svejnar (2001) imply that large Czech firms operated under soft budget constraints. According to the EBRD, the Czech government subsidized enterprises much more heavily, allocating around 7.4 percent of GDP during 1993-1996, compared to 1.5 percent in Estonia over this period.

Comparing the tax environment, Estonia appears somewhat friendlier. As shown in Table A.1, tax revenues as a share of GDP were higher in the Czech Republic than in Estonia, where corporate income tax policies were lower. (In Estonia the corporate income tax was lowered from a flat rate of $35 \%$ in 1992 to a flat rate of $26 \%$ in 1995; the Czech corporate income tax was also gradually lowered from $45 \%$ in 1993 to 39\% in 1996.) Further, a study by Riboud and SilvaJaregui (2001) shows the tax burden on labor is very high in the Czech Republic at the end of the 1990 s, with total tax burden at $80 \%$ of labor costs, including a payroll tax of $46 \%$; in Estonia, the relevant tax rates are $62 \%$ and $35 \%$, respectively.

Finally, in addition to providing a softer environment for the old firms, the Czechs offered generous non-employment benefits for the workers who were laid off. In the first year of transition, the Czechs were offered 12 months of unemployment benefits entitlement. As the transition proceeded the Czechs tightened their unemployment benefit system, reducing the entitlement period to six months while keeping the replacement rate between $50-60 \%$ of the previous wage. Whereas the entitlement period was the same for the Estonian unemployed, the replacement rate was only $7-10 \%$. After the entitlement for unemployment benefit ends, all poor Czech households are able to receive welfare indefinitely whereas only the Estonian families with three or more children can receive welfare assistance and only for up to three months. 


\section{APPENDIX TABLES}

Table A.1: Macroeconomic Statistics for the Czech Republic and Estonia

\begin{tabular}{|c|c|c|c|c|c|c|c|c|c|}
\hline & & \multicolumn{8}{|c|}{ Years since the start of Transition* } \\
\hline & & -2 & -1 & $\mathbf{0}$ & 1 & 2 & 3 & 4 & 5 \\
\hline \multirow[t]{2}{*}{ Real GDP Growth ${ }^{\mathrm{a}}$} & Czech Republic & 1.4 & -1.2 & -11.6 & -0.5 & 0.1 & 2.2 & 5.9 & 4.8 \\
\hline & Estonia & -6.5 & -13.6 & -14.2 & -8.8 & -2.0 & 4.6 & 4.0 & 10.4 \\
\hline \multirow[t]{2}{*}{ Inflation $^{\mathrm{b}}$} & Czech Republic & 1.4 & 9.7 & 52.0 & 11.1 & 20.8 & 10.0 & 9.1 & 8.8 \\
\hline & Estonia & 23.1 & 211.0 & 1076.0 & 89.8 & 47.7 & 29.0 & 23.1 & 11.2 \\
\hline \multirow[t]{2}{*}{ Real Wages Index ${ }^{c}$} & Czech Republic & 145 & 136 & 100 & 110 & 114 & 123 & 134 & 146 \\
\hline & Estonia & 227 & 151 & 100 & 102 & 113 & 119 & 122 & 131 \\
\hline \multirow[t]{2}{*}{ Unemployment Rate } & Czech Republic $^{d}$ & & 0.7 & 4.1 & 2.6 & 3.5 & 3.2 & 2.9 & 3.5 \\
\hline & Estonia $^{e}$ & 0.5 & 0.9 & 2.1 & 5.8 & 7.6 & 9.7 & 10.0 & 9.7 \\
\hline \multirow[t]{2}{*}{ Savings $(\% \text { of GDP })^{f}$} & Czech Republic & & & 0.32 & 0.29 & 0.32 & 0.28 & 0.30 & 0.29 \\
\hline & Estonia & & 0.36 & 0.33 & 0.22 & 0.16 & 0.19 & 0.16 & 0.19 \\
\hline \multirow[t]{2}{*}{ Exchange rate ${ }^{g}$} & $C Z K / U S D$ & & & 28 & 28.29 & 29.16 & 28.78 & 26.55 & 27.14 \\
\hline & $E E K / U S D$ & & & & 13.23 & 12.97 & 11.46 & 12.03 & 13.90 \\
\hline \multirow{2}{*}{ Tax Revenue (\% of GDP) ${ }^{h}$} & Czech Republic & & & & & & 42.6 & 41.9 & 40.3 \\
\hline & Estonia & & & & & 35.4 & 36.1 & 38.8 & 40.6 \\
\hline Effective Statutory Social & Czech Republic & & & & & 88.2 & 91.9 & 91.7 & 90.8 \\
\hline Security Tax $(\%)^{\mathbf{i}}$ & Estonia & & & 73.3 & 84.3 & 81.2 & 76.6 & 81.6 & 82.9 \\
\hline Budgetary Subsidies to & Czech Republic & & & & & 6.4 & 7.1 & 8.3 & 8.0 \\
\hline Enterprises (\% of GDP $)^{j}$ & Estonia & & & & 1.5 & 1.4 & 1.9 & 0.9 & 0.3 \\
\hline
\end{tabular}

* The start of transition is 1991 for the Czech Republic and 1992 for Estonia.

Sources:
(a) EBRD Transition Report Update, April 2001 p. 15
(b) EBRD Transition Report, 2000 p. 67
(c) Unicef, (1999) CEE/CIS/Baltics Regional Monitoring Report, 1999. Unicef, Florence. P141
(d) Czech Republic: EBRD Transition Report 2000 and Business Central Europe Database
(e) Estonian Labor Force Survey 1995 (incl. Retrospective) and 1997 (Vodopivec, 2000)
(f) World Development Indicators
(g) Bank of Estonia and Czech National Bank
(h) EBRD Transition Report, November 2001 p. 63
(i) EBRD Transition Report, November 2001 p. 136, 140: Ratio of effective collection of social security taxes over total labor income in the economy, divided by the statutory social security tax rate. A collection of 6 per cent of total payroll for a statut
(j) EBRD Transition Report, November 2001 p. 136, 140: Budgetary transfers to enterprises and households, excluding social transfers. In the Czech Republic this includes transters to Konsolidacni Banka. 
Table A.2: Czech Retrospective Data

\begin{tabular}{lr}
\hline \hline Sample counts & \\
Number of workers & 4786 \\
Number of spells (jobs) & 7924 \\
Number of spells that ended within sampling frame & 4010 \\
\hline Reported distribution of exits (initial JD estimate bolded) & \\
a. I stopped my business & $\mathbf{1 . 8 \%}$ \\
b. My employer stopped his business & $\mathbf{1 1 . 8 \%}$ \\
c. Laid off due to reduction of workforce & $\mathbf{7 . 4 \%}$ \\
d. Laid off due to other reasons & $2.4 \%$ \\
e. I was not satisfied with my job, or I found a better job & $28.9 \%$ \\
f. I quit myself due to personal or family reasons & $13.8 \%$ \\
g. I quit on the health ground & $5.7 \%$ \\
h. School attendance, study, training & $5.4 \%$ \\
i. Army service, civil service & $2.0 \%$ \\
j. I moved & $0.7 \%$ \\
k. Retirement & $10.3 \%$ \\
l. Maternity leave & $6.2 \%$ \\
m. Other reasons & $10.0 \%$ \\
Total & $106.5 \%$ \\
\hline
\end{tabular}


Table A.3: Estonian Retrospective Data

\begin{tabular}{lr}
\hline \hline Sample counts & \\
Number of workers & 7928 \\
Number of spells (jobs) & 14465 \\
Number of spells that ended within sampling frame & 8821 \\
\hline Reported distribution of exits (initial JD estimate bolded) & \\
a. Closing of the enterprise/organization & $\mathbf{7 . 4 \%}$ \\
b. Reorganization of the enterprise/organization & $\mathbf{8 . 4 \%}$ \\
c. Bankruptcy of the enterprise/organization & $\mathbf{2 . 3 \%}$ \\
d. Privatization of the enterprise/organization & $\mathbf{0 . 8 \%}$ \\
e. Dissmissal initiated by employer & $2.9 \%$ \\
f. Personnel Reduction & $\mathbf{1 2 . 4 \%}$ \\
g. Expiration of employment contract & $4.9 \%$ \\
h. Expiration of the trail time & $0.3 \%$ \\
i. Army service & $1.3 \%$ \\
j. Imprisonment & $0.2 \%$ \\
k. Illnes/injury & $4.4 \%$ \\
l. Studies & $1.9 \%$ \\
m. Retirement & $9.8 \%$ \\
n. Marriage/child birth & $6.8 \%$ \\
o. Change of residence & $2.5 \%$ \\
p. Wanted/was proposed higher salary & $13.6 \%$ \\
q. Wanted/was proposed better working conditions & $9.2 \%$ \\
r. Wanted/was proposed more interesting work & $5.8 \%$ \\
s. Wanted to start own business & $2.6 \%$ \\
t. Main job become second job & $0.5 \%$ \\
Total & $98.0 \%$ \\
\hline \hline &
\end{tabular}

* Note: After correction for JC $<0$ (Section 4), the results are not sensitive to alternatively choosing first 8 answers as corresponding to JD. 


\section{Appendix Figures}

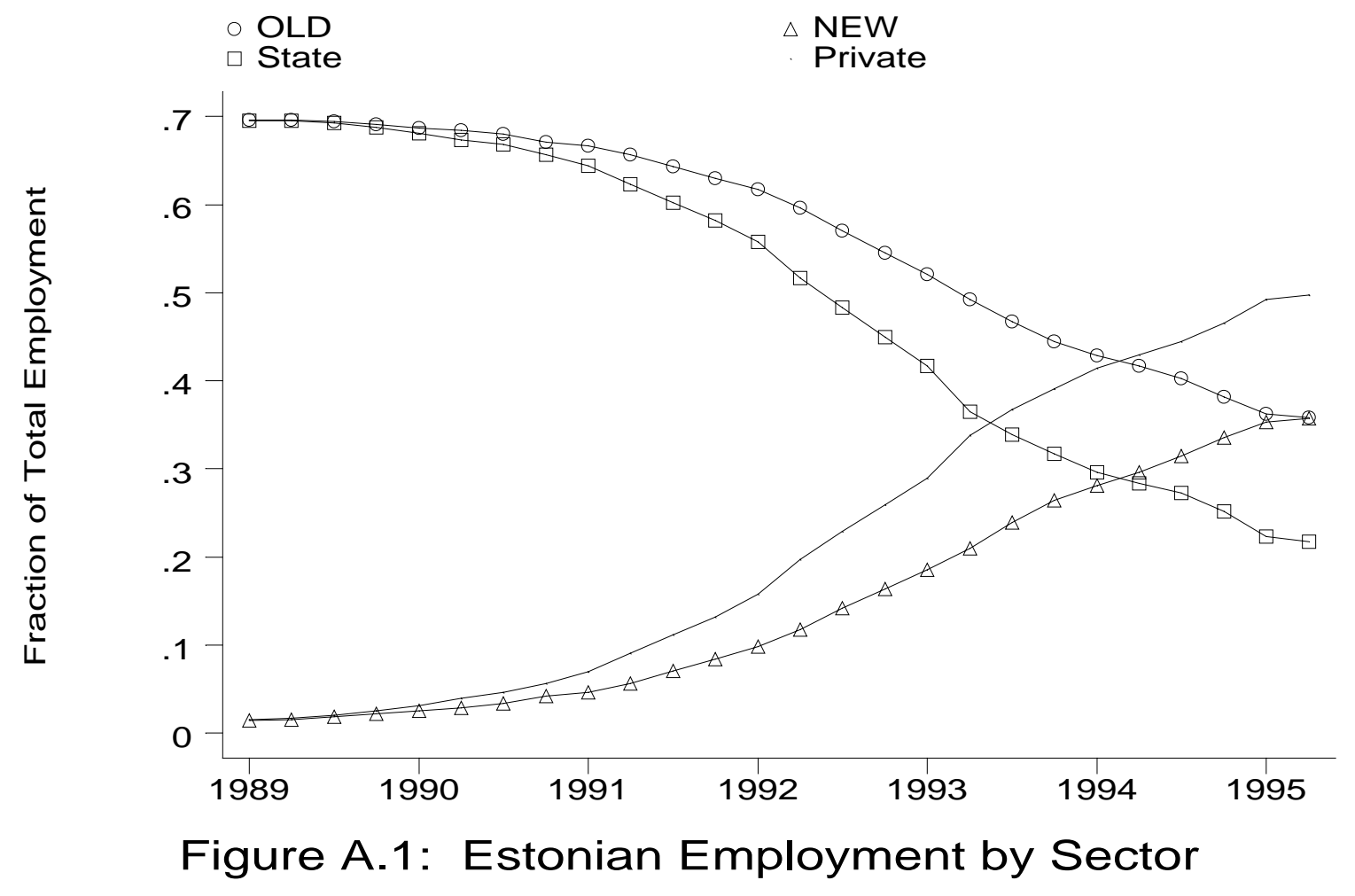




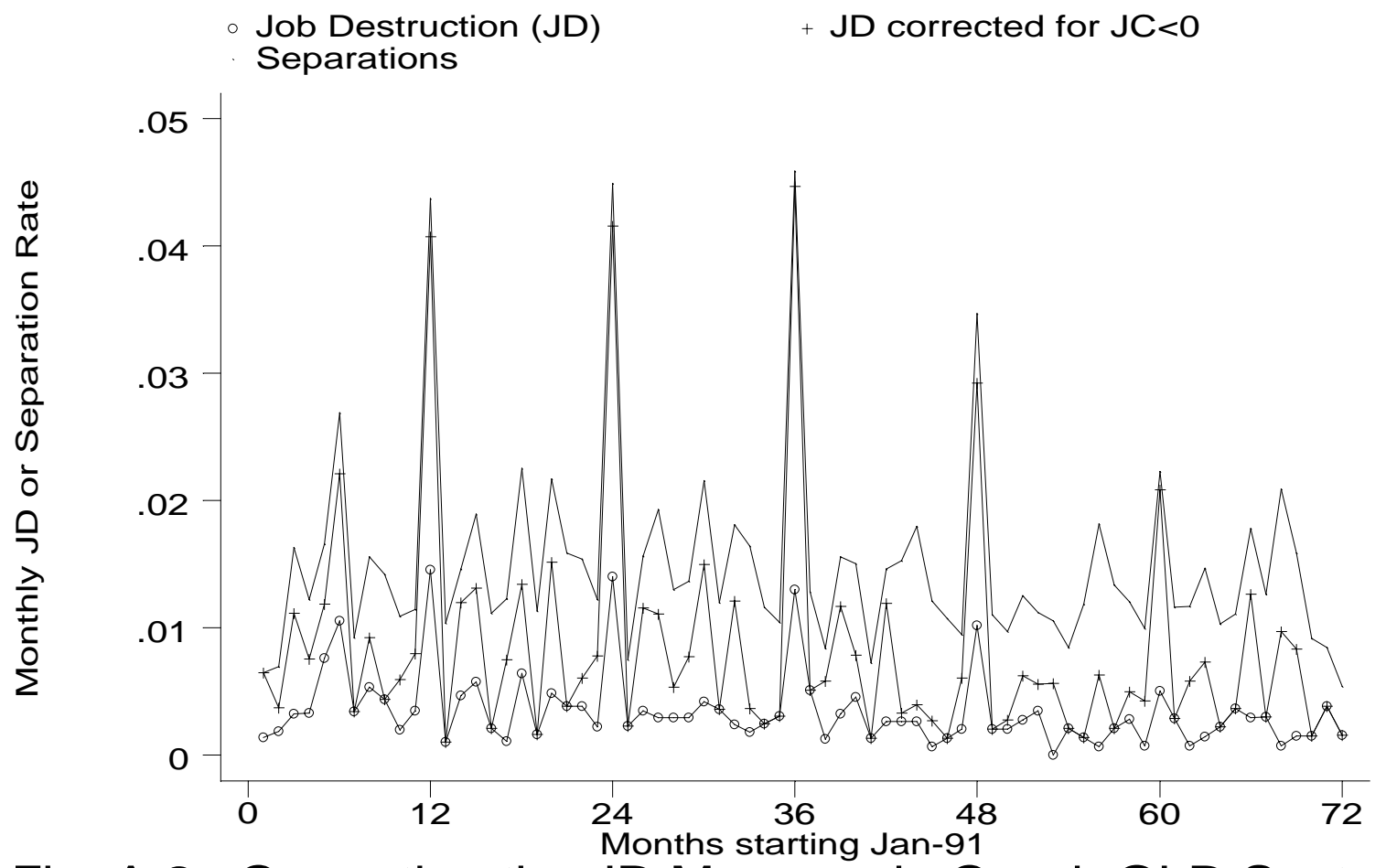

Fig. A.2: Correcting the JD Measure in Czech OLD Sector

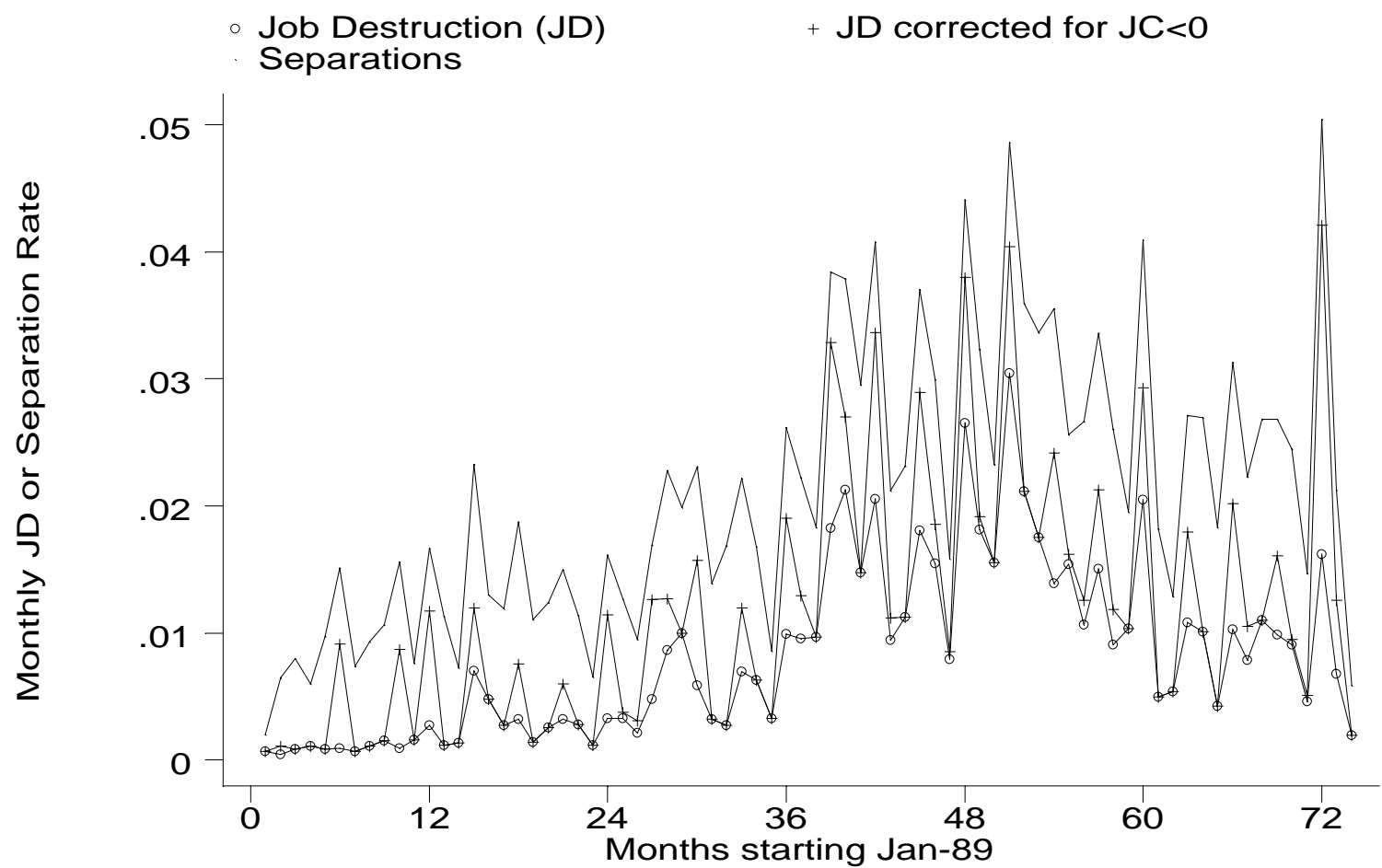

ig. A.3: Correcting the JD Measure in Estonian OLD Sectc 


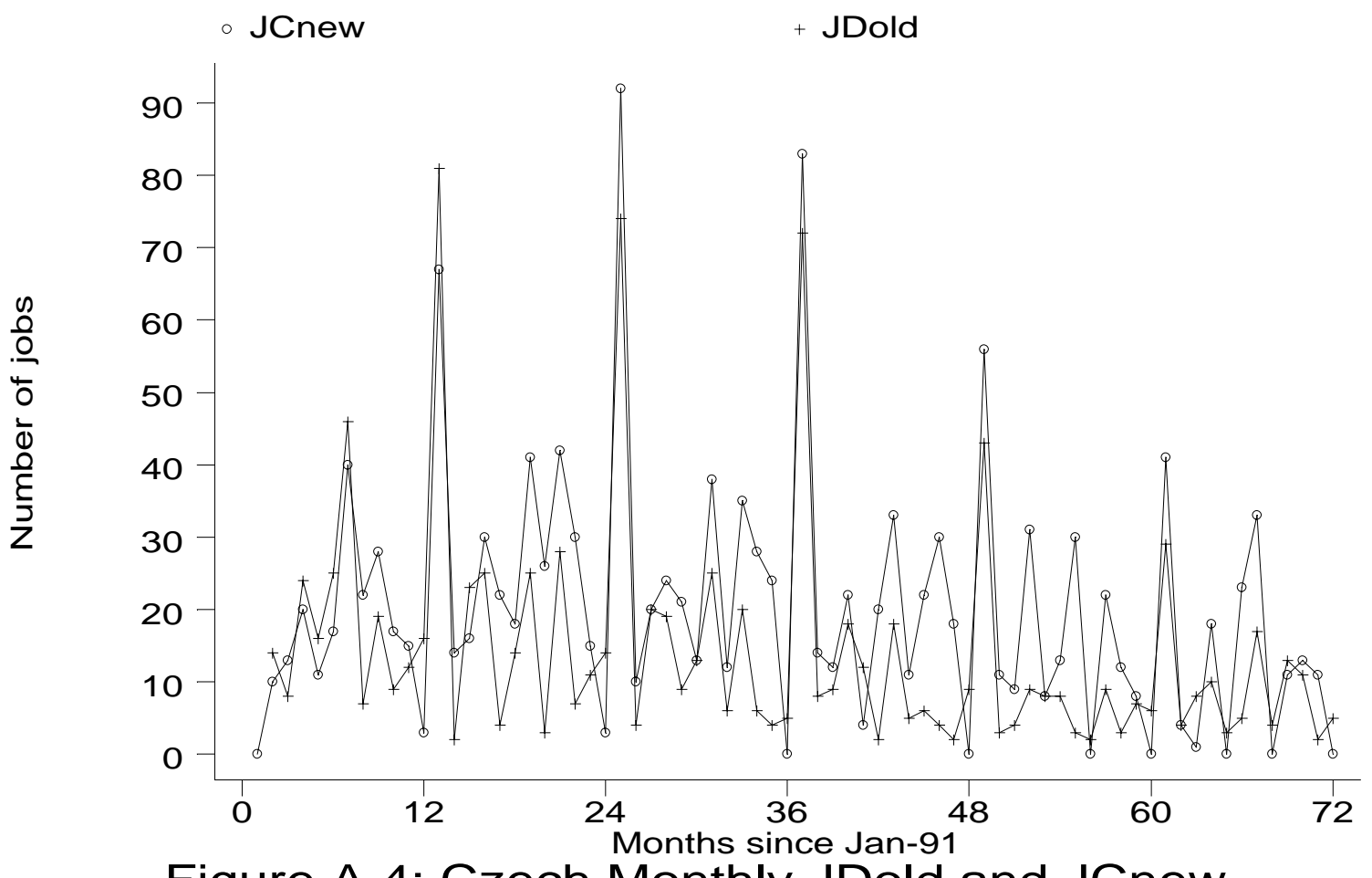

Figure A.4: Czech Monthly JDold and JCnew

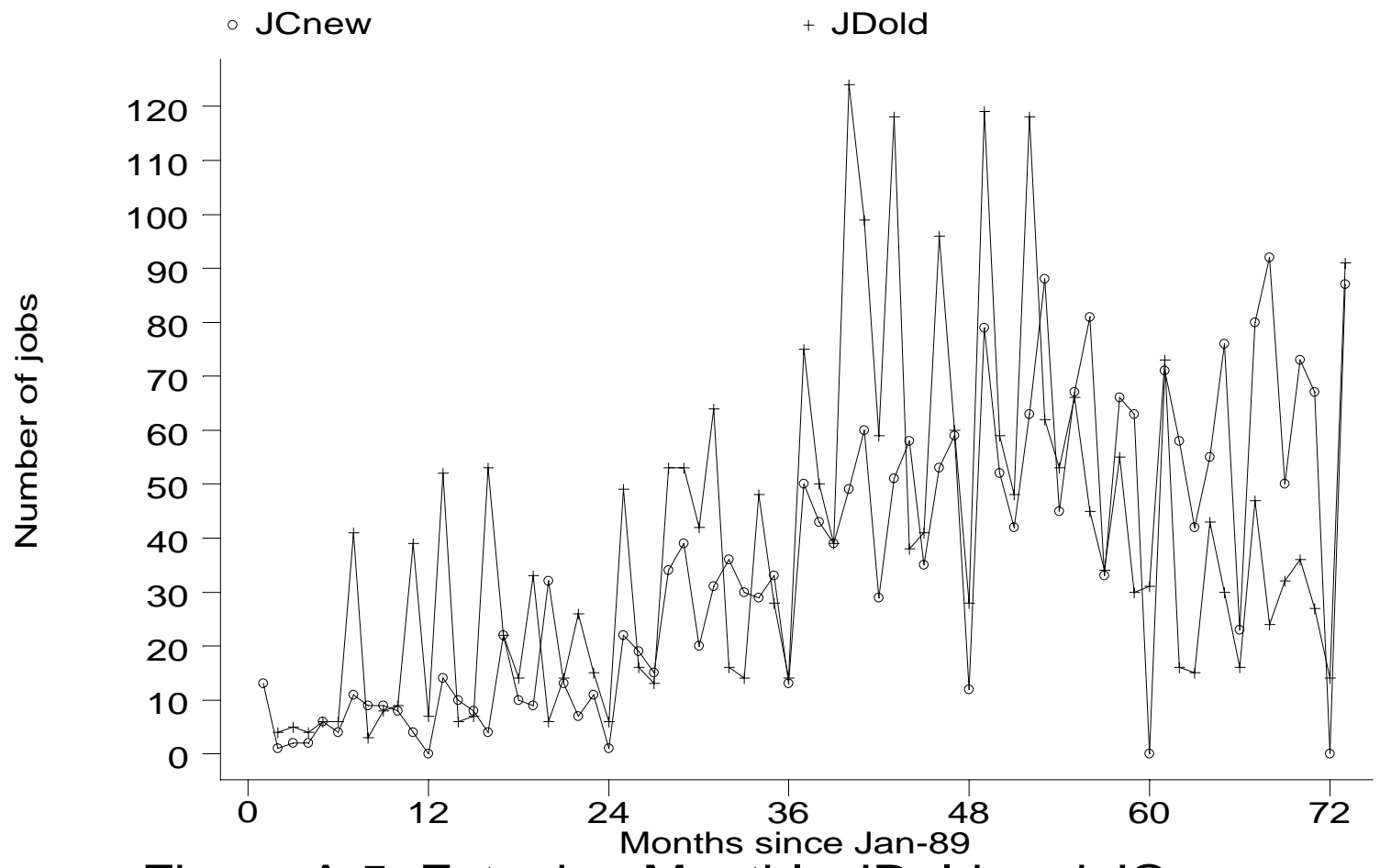

Figure A.5: Estonian Monthly JDold and JCnew 


\section{DAVIDSON INSTITUTE WORKING PAPER SERIES - Most Recent Papers}

The entire Working Paper Series may be downloaded free of charge at: www.wdi.bus.umich.edu

CURRENT AS OF 1/31/02

\begin{tabular}{|c|c|c|}
\hline Publication & Authors & Date \\
\hline $\begin{array}{l}\text { No. 432: What Drives the Speed of Job Reallocation During Episodes of } \\
\text { Massive Adjustment }\end{array}$ & $\begin{array}{l}\text { Stepan Jurajda and Katherine } \\
\text { Terrell }\end{array}$ & Jan. 2002 \\
\hline No. 431: Competition and Corporate Governance in Transition & Saul Estrin & Dec. 2001 \\
\hline $\begin{array}{l}\text { No. 430: Corporate Governance in the Cause of Peace: An } \\
\text { Environmental Perspective }\end{array}$ & Don Mayer & Jan. 2002 \\
\hline No. 429: Why do Governments Privatize? & $\begin{array}{l}\text { Loren Brandt, Hongbin Li, and } \\
\text { Joanne Roberts }\end{array}$ & Dec. 2001 \\
\hline No. 428: Testing Russia's Virtual Economy & Vlad Ivanenko & Dec. 2001 \\
\hline No. 427: War and the Business Corporation & Eric W. Orts & Dec. 2001 \\
\hline $\begin{array}{l}\text { No. 426: Partial Privatization and Firm Performance: Evidence from } \\
\text { India }\end{array}$ & Nandini Gupta & Dec. 2001 \\
\hline $\begin{array}{l}\text { No. 425: Direct Foreign Investments and Productivity Growth in } \\
\text { Hungarian Firms, 1992-1999 }\end{array}$ & Jérôme Sgard & Nov. 2001 \\
\hline $\begin{array}{l}\text { No. 424: Banking Passivity and Regulatory Failure in Emerging } \\
\text { Markets: Theory and Evidence from the Czech republic. }\end{array}$ & Jan Hanousek and Gerard Roland & July 2001 \\
\hline $\begin{array}{l}\text { No. 423: Conceptions of the Corporation and the Prospects of } \\
\text { Sustainable Peace }\end{array}$ & Jeffrey Nesteruk & Dec. 2001 \\
\hline No. 422: The Role of the Corporation in Fostering Sustainable Peace & Timothy Fort and Cindy Schipani & Nov. 2001 \\
\hline No. 421: Wage Arrears and the Distribution of Earnings in Russia & $\begin{array}{l}\text { Hartmut Lehmann and Jonathan } \\
\text { Wadsworth }\end{array}$ & Dec. 2001 \\
\hline $\begin{array}{l}\text { No. 420: Transferring Collective Knowledge: Collective and } \\
\text { Fragmented Teaching and Learning in the Chinese Auto Industry }\end{array}$ & $\begin{array}{l}\text { Jane Zhou, Jaideep Anand, and } \\
\text { Will Mitchell }\end{array}$ & Dec. 2001 \\
\hline $\begin{array}{l}\text { No. 419: Liberalization, Corporate Governance, and the Performance of } \\
\text { Newly Privatized Firms }\end{array}$ & $\begin{array}{l}\text { Narjess Boubakri, Jean-Claude } \\
\text { Cosset, and Omrane Guedhami }\end{array}$ & Dec. 2001 \\
\hline $\begin{array}{l}\text { No. 418: The European Data Privacy Directive and International } \\
\text { Relations }\end{array}$ & Steven R. Salbu & Dec. 2001 \\
\hline $\begin{array}{l}\text { No. 417: Capital Markets and Capital Allocation: Implications for } \\
\text { Economies in Transition }\end{array}$ & $\begin{array}{l}\text { Artyom Durnev, Randall Morck, } \\
\text { and Bernard Yeung }\end{array}$ & Dec. 2001 \\
\hline $\begin{array}{l}\text { No. 416: Forthcoming in: The Journal of Economic Perspectives, "Data } \\
\text { Watch. Research Data from Transition Economies," 16(2) Feb. } 2002 .\end{array}$ & $\begin{array}{l}\text { Randall K. Filer and Jan } \\
\text { Hanousek }\end{array}$ & Dec. 2001 \\
\hline $\begin{array}{l}\text { No. 415: Forthcoming in: The Journal of Economic Perspectives, } \\
\text { "Transition Economies: Performance and Challenges," 16(2) Feb. } 2002 .\end{array}$ & Jan Svejnar & Dec. 2001 \\
\hline $\begin{array}{l}\text { No. 414: Forthcoming in: The Journal of Economic Perspectives, "The } \\
\text { Great Divide and Beyond: Financial Architecture in Transition," 16(2) } \\
\text { Feb. 2002. }\end{array}$ & Erik Berglof and Patrick Bolton & Dec. 2001 \\
\hline $\begin{array}{l}\text { No. 413: Forthcoming in: The Journal of Economic Perspectives, "The } \\
\text { Political Economy of Transition," 16(2) Feb. } 2002 .\end{array}$ & Gérard Roland & Dec. 2001 \\
\hline $\begin{array}{l}\text { No. 412: The Response of Consumption in Russian Households to } \\
\text { Economic Shocks }\end{array}$ & Steven Stillman & Oct. 2001 \\
\hline No. 411: Mark-ups in Hungarian Corporate Sector & László Halpern and Gábor Körösi & Aug. 2001 \\
\hline $\begin{array}{l}\text { No. } 410 \text { Forthcoming in: European Economic Review, "Economic } \\
\text { Development, Legality, and the Transplant Effect." }\end{array}$ & $\begin{array}{l}\text { Daniel Berkowitz, Katarina } \\
\text { Pistor, Jean-Francois Richard }\end{array}$ & Sept. 2001 \\
\hline No. 409: Development Strategy, Viability, and Economic Convergence & Justin Yifu Lin & Oct. 2001 \\
\hline No. 408: Labor Supply, Informal Economy and Russian Transition & Maxim Bouev & May 2001 \\
\hline No. 407: Corporate Governance in China: Then and Now & Cindy Schipani and Liu Junhai & Nov. 2001 \\
\hline No. 406: Entrepreneurship and Post-Socialist Growth & $\begin{array}{l}\text { Daniel Berkowitz and David N. } \\
\text { DeJong }\end{array}$ & Oct. 2001 \\
\hline $\begin{array}{l}\text { No. 405: Forthcoming in: European Economic Review, "Policy Reform } \\
\text { and Growth in Post-Soviet Russia." }\end{array}$ & $\begin{array}{l}\text { Daniel Berkowitz and David N. } \\
\text { DeJong }\end{array}$ & Oct. 2001 \\
\hline
\end{tabular}

